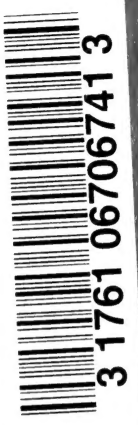

2001

Aves

$\mathrm{T}$

Taverner, Percy Algernon

Birds of the reda Deer River, Alberta. 



\section{Zool Aves}

T

\section{THE BIRDS}

OF THE

RED DEER RIVER ALBERTA

By P. A. TAVERNER
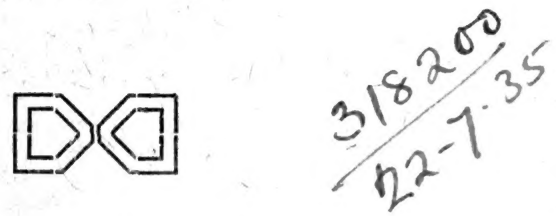

Reprinted from The Auk, Vol. XXXVI.

No. 1. January, 1919, pp. 1-21. No. 2. April, 1919, pp. 248-265.

Platés I-IV. 



\section{Digitized by the Internet Archive in 2007 with funding from Microsoft Corporation}




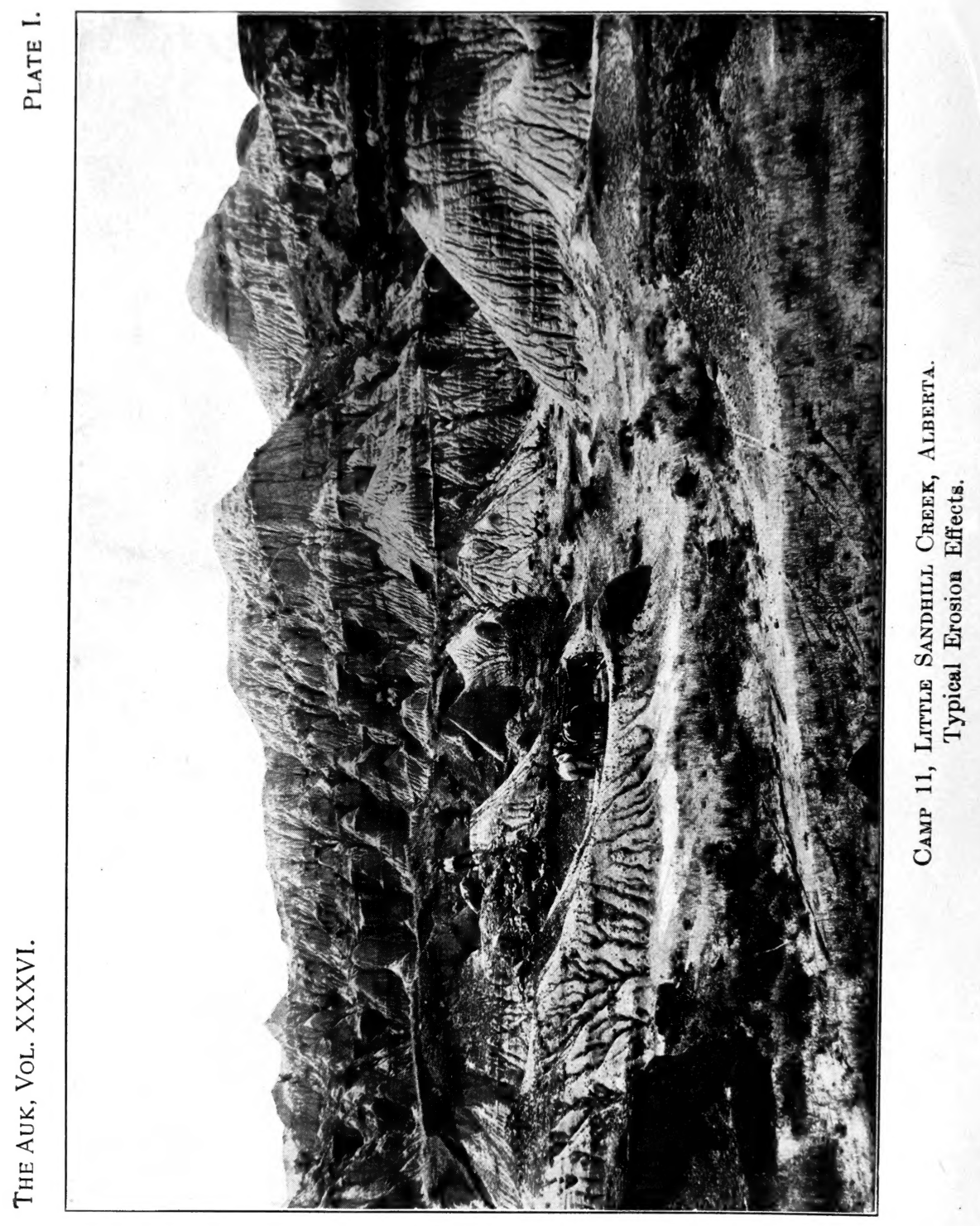




\title{
THE BIRDS OF THE RED DEER RIVER, ALBERTA.
}

\author{
BY P. A. TAVERNER. ${ }^{1}$
}

\section{Plates $I-I V$.}

ThE region about Red Deer and Calgary, Alta., has received the attention of several ornithological observers; but while individual notes and specimens from there are scattered through many publications and various collections no attempt has been made to correlate or bring them all together. During the summers of 1915 and 1916 the Geological Survey of Canada had parties collecting large fossils in the Edmonton and Belly River formations in the bad-lands of the Red Deer River. Incidental to this work Mr. George Sternberg of this museum collected a number of interesting birds. His account of the country and the ornithological specimens he secured, added to the fragmentary references in literature, proved so interesting that it was decided to make a more intensive ornithological investigation of the river during the summer of 1917.

June 18 found the writer and C. H. Young in Red Deer, where a rough scow-shaped boat was built, sixteen feet long and four and a half feet wide, capable of carrying ourselves and a comfortable amount of camp and collecting equipment. An outboard motor was attached and the descent of the river begun on June 25 . While on the subject it may be well to state that this outfit was eminently 
satisfactory. The rather clumsy boat and low power motor while not adapted for navigating against the current were admirable for going with it, and had the trip to be made over again I know of no important detail that might be altered.

The river was at about mid-height. The high spring floods were past but the water had not reached its low summer level. No rapids of importance were encountered and in only two places was navigation more than mildly exciting. The first was the "Canyon," some twenty-five miles from Red Deer via the river, though only eight miles overland. The other was just above the Grand Trunk Pacific Railway crossing south of Alix between camps 3 and 4 . We had heard from residents of the danger of these places and probably at certain stages of water they may be bad, but when we passed we found that the risk had been much exaggerated.

From Red Deer to Drumheller the river was usually deep and water could always be found for much deeper draught than ours. Occasional shallows occurred and islands divided the current, necessitating some care in choosing the proper channel. It was necessary also to put such a motor as we had on a hinge to avoid disaster when through misjudgment the wrong channel was taken and shallow water was unexpectedly encountered. A little above Drumheller and continuing below, the river widens and shallows and the bottom changes from boulder and gravel to sandy mud, forming shifting shoals between which the channel meanders confusingly, rendering navigation more complicated though mistakes were annoying rather than serious.

The whole valley of the river lies some 100 to 250 feet below the general prairie level. Above Nevis, Camp 4, it is comparatively narrow and bounded by simple hills, steep bluffs or rocky cliffs, usually as well covered with vegetation as the slope and age of exposure permits. The prairie begins close to the river at the verge of the first embankment and the ox-bow bends are well wooded. Below Nevis the aspect of the landscape changes considerably, bare, raw, freshly eroded exposures are the rule and badland conditions are assumed. The ox-bows are extensive gumbo flats with the woods confined to the river edge; otherwise bare bluffs rise straight from the water, or raw clay hills, striped horizontally with black coal seams, succeed each other as far as the eye 
can reach, shaped by the elements into strange forms, gashed into gullies with sharp knife-edged buttresses between, or carved into domes and sugar loaf shapes. Between Camps 9 and 10 this sculpturing becomes more pronounced and stranger still. The domes are more conical, their sides steeper, vertical cliffs and sinkholes are more common and the sky line more ragged. Gothic cathedral outlines replace Byzantine domes and the landscape exhibits a confusion of buttressed spires and balanced rock-capped pinnacles.

The country about Red Deer is rolling prairie of varied and interesting aspect with considerable spruce bush covering the hills and following watercourses. On the river, as far as Nevis, spruce of considerable size is a conspicuous element in the vegetation, ascending the hills on either hand wherever root hold can be obtained, while the stream margin is well clothed with poplar, birch and willow. Below Nevis the spruce gets less common and smaller, and within a few miles further down exists only as small scrub covering the higher and colder slopes. Below Drumheller it ceases to exist at all. As the spruce gives out the cottonwood along the banks takes on a larger and stronger growth. Wherever the swing of the river has built up an alluvial plain the margins are well wooded for a hundred yards or so back from the water. Most of this is cottonwood and large trees with great rough trunks and spreading branches like grove-grown oaks occur commonly. The smaller shrubbery is largely saskatoon or willow and alder. This character of vegetation persists, except on the eroded banks, to near Steveville, Camp 10, below which the timber becomes smaller and scantier, and at our final Camp 11, even tent poles were difficult to find and sage brush and prickly pear cactus generally came down to the river banks.

The ecological conditions follow the physiographical aspects. About Red Deer and nearly to Nevis the river valley is mesophytic, while below drier conditions prevail, until at our last station, Camp 11, below Steveville, the raw bare landscape, scanty buffalo grass, sage brush and prickly pear cactus proclaimed the typical desert, except here and there on the narrow flood banks and in traces along the lower courses of occasional intermittent creeks.

The river valley as far as we followed it is practically unin- 
habited. Here and there on the most promising of the wider bends little ranch establishments peep out of the wooded shores, but many of them in war time, alas, were closed and deserted, others seem to have been occupied only long enough to obtain legal homestead title, and only a few of them were occupied. Grazing is the principal industry in such places and most of the bush margin is traversed by cattle paths. However, though scarcely a soul was visible throughout most of the trip, we had only to climb to the prairie level to find some of the most fruitful and best cultivated lands in the Canadian west: so, though apparently traveling in the wilderness, we were really never far out of touch with settled communities. This was especially true and striking on the upper reaches and down as far as the Tolman Ferry, Camp 6, where we made our last excursion out of the valley. At the last camp, No. 11, when we finally left the river, the upper level conditions were rather different, and wide reaches of dry flat prairie dotted occasionally with bunches of cattle and horses and only suitable for cultivation by aid of the irrigation project of the Canadian Pacific Railroad met the eye from the river to the railroad at Millicent.

We left Red Deer June 25, arriving at Camp 11 near Steveville, 217 miles below, July 19 . This was the site of the Survey's palaeontological collecting camp under Mr. Chas. Sternberg and here C. H. Young remained until September 26, but the writer left for British Columbia July 21. During this trip, occupying about a month, no regular schedule was followed and we remained stationary or moved to the next location as local conditions suggested. The weather after the first day or two at Camp 1 was ideal for our work and we were even spared, by the seasonal conditions, serious trouble from mosquitoes that report had led us to expect to be bad. All who travel on the river do not escape so easily. Once or twice we camped too close to cattle herds and for our lack of foresight were vexed with flies. These were a more serious menace to our specimens than to us and our slow drying specimens of young raptores were seriously threatened by the pests. Careful screening of our drying trays however prevented further loss than the disfigurement of a few individual specimens.

Our first camp (No. 1) was made some twenty-seven miles below Red Deer, though only some $8-9$ miles by road and just after we 
passed the "Canyon." Here we remained until July 4, working the uplands as well as the valley, and obtained a fairly representative collection of the birds of the locality and an idea of the general conditions. Most species were breeding and all were very shy and retiring. We were further handicapped by being disinclined to take adults having families dependent upon them. This increased the work and limited practical results. From here on we made but short stops at varying distances and except at Camp 4, near Nevis, and at Camp 6, Tolman's Ferry, confined our attentions to the river valley itself.

At Camp 11, after the writer left, Young made a general survey of the locality, worked thoroughly all the surrounding territory within walking distance and made as complete a collection as possible. As he remained until the fall migrations were well under way he added many species to our list. His material is of exceptional interest as can be seen in the following annotations.

I have included in the list references to the collections made by Mr. Geo. Sternberg in 1915 and 1916 as well as some specimens collected by Mr. Chas. Horsbrough at Alix, in the vicinity of the upper river, besides occasional other notes from the same general locality. Those accredited to G. F. Dippie are cited, unless otherwise stated, from the 'Catalogue of Canadian Birds,' J. and J. M. Macoun, 1909. A good many specimens from this neighborhood are extaht in various collections and should any reader of 'The Auk' have additional material or information I should be pleased to have it published as addenda to this list.

Since writing the above, a paper entitled 'Further Notes on the Birds Observed at Alix, Buffalo Lake and Red Deer, Alta., in 1915 and 1916' by Chas. B. Horsbrough, has appeared in 'The Ibis' for July 1918, pp. 417-496, giving annotations on ninety-five species and calling attention to a previous paper by the same author, 'Ornithological Notes from Alix and Buffalo Lake Districts, Alta., in 1914, Ibid., October, 1915, pp. 670-689, annotating eighty species. From these two lists much additional data has been extracted and a number of species added to our list. Mr. Horsbrough's rather free use of subspecific designations is a little disconcerting. In a few cases he has given his authority for his decisions but the majority are evidently made on geographical assumptions and hence whilst 
most of his specific determinations can be confidently received I have not allowed his finer divisions to influence me. In this I am not wishing to criticise the writer personally, only the current system which he follows. As I may myself be called to task for sins of subspecific determination I wish to state that my decisions are based entirely upon the material in view and it is not the intention to cast reflections upon the conclusions of others or those based upon different material. I also wish to be judged by the letter of my statements and not upon inferences that may be read into them. Many of my conclusions are contrary to accepted authority, but in explanation I herewith quote from 'one whose authority can not be questioned and whose words though written in support of a somewhat opposite standpoint interpret my attitude much better than I can express it myself. The bracketed interpolations are mine,- " No doubt many of the forms which the author has [or has not] recognized as subspecies in the present work may [or may not] appear trivial [or important] to others, especially those who have not had the advantage of the material upon which they are based; but in all cases it has been the author's desire to express exactly the facts as they appear to him in the light of the evidence examined, without any regard whatever to preconceived ideas, either his own or others', and without consideration of the inconvenience which may result to those who are inclined to resent innovations, forgetful of the fact that knowledge can not be complete until all is known." 1

The following is a schedule of the Camps which are referred to in the annotations. The fractional camp numbers in the text refer to occurrences en route between camps. Mileage is by the river as the boat traveled.

Camp 1.- 25 Miles below Red Deer, June 25-July 4.

Camp 2.- $30 \quad$ Miles below Red Deer, July 4-5.

Camp 3.- 37.65 Miles below Red Deer, July 5-6.

Camp 4.- 55.80 Miles below Red Deer, the Pump-house near Nevis, July 6-9.

Camp 5.- 83.40 Miles below Red Deer, Ross's Ranch, July 9-11.

${ }_{1}$ Robert Ridgway, Birds of North and Middle America, Vol. I, 1901, pp x-xi. 


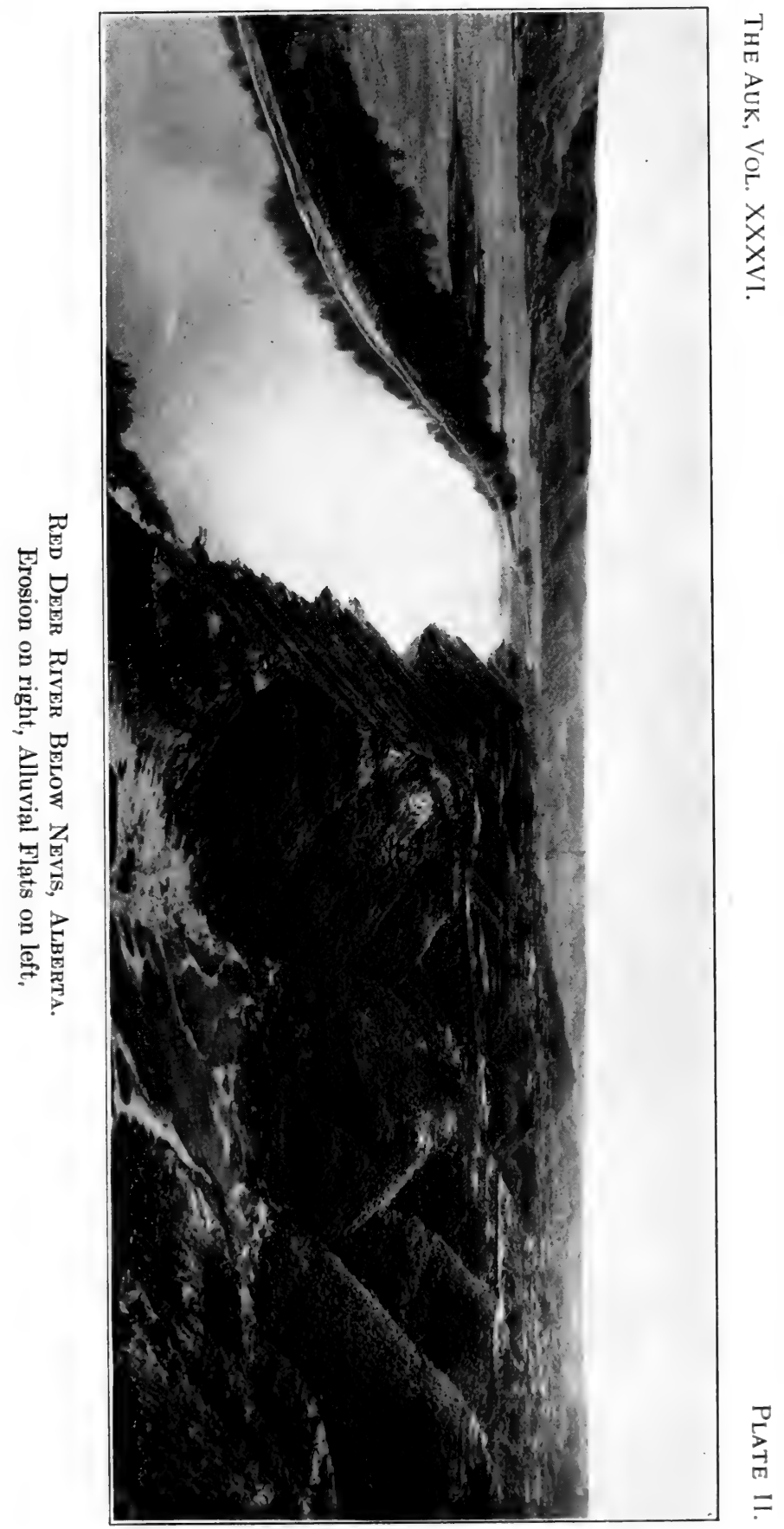



Camp 6.- 97.20 Miles below Red Deer, Tolman's Ferry, July 11-13.

Camp 7.-132.00 Miles below Red Deer, Drumheller, July 1314.

Camp 8.- 139.50 Miles below Red Deer, near Rosedale Mines, July 14-17.

Camp 9.-163.20 Miles below Red Deer, 31-20 below Drumheller, July 17-18.

Camp 10.-213.60 Miles below Red Deer, 1 mile above Steveville, July 18-19.

Camp 11. - 217.50 Miles below Red Deer, 3 miles below Steveville, July 19-September 26.

1.* Echmorphorus occidentalis. Western GreBe.-Two birds collected by Horsbrough, Buffalo Lake, near Alix Alta, June 1914, where he reports them breeding commonly. One of these, a female, is the form with slender recurved bill, once called Clarke's Grebe, $\boldsymbol{E}$. clarki.

2.* Colymbus holbœlli. Holbcell's Grebe. - Three seen on Brock's Lake at Camp 1: a female taken contained an egg ready to lay. Seen also on small pond near Bullocksville with young and on small waters in vicinity of Nevis. Though lakes apparently admirably adapted to them were examined on the upper levels at Tolman Ferry, no birds were noted upon them. Horsbrough reports them rare on Buffalo Lake but common on many smaller waters.

3.* Colymbus auritus. Horned Grebe.-A pair with nest containing a partially hatched brood was found on a small slough near Camp 1 and all collected. Only two seen thereafter at Camp 11 after the writer left, one juvenile being taken in extremely emaciated condition. This can probably be explained by the extremely muddy condition of the water preventing the bird from seeing its prey.

4.* Colymbus nigricollis. EAred Grebe.-We saw no Eared Grebe ourselves but we have a specimen taken by Charles Horsbrough at Buffalo Lake, near Alix, June 11, 1914. He mentions the species in neither of his lists.

5. Podilymbus podiceps. PIEd-BILled Grebe.- Horsbrough reports a pair breeding on a small pond near Alix and commonly on Buffalo Lake in 1914.

6. Gavia immer. Common Loon.- Reported as being occasionally seen on Brock's Lake, Camp 1, on whose shores we found the decomposed remains of a single specimen. Horsbrough does not regard it as common.

7.* Larus delawarensis. Ring-BILled Gull.-After July 8 at

* The asterisk denotes that specimens were taken or are in the collection of the Museum of the Geological Survey of Canada. 
Camp 4 we saw occasional large gulls of the Ring-bill type but it was not until the 12th on a small lake near Tolman's Ferry that a specimen was secured and identified. It is an adult non-breeding male. The bill was yellow with dark spots on the mandibles not forming a complete ring. The inside of mouth was orange shading to bright red in throat and showing externally at the gape. Eye-ring vermilion. The legs and feet are clear chrome yellow instead of the greenish yellow that most of the written descriptions call for. It is not impossible that these prairie birds will be found to be distinguishable from the eastern race on the basis of leg coloration. Colored drawings of the soft parts were from the fresh specimen.

8.* Larus franklini. Frankuin's GuLL. - Seen almost daily in singles to occasional fairly large flocks as far as Camp $8 \frac{1}{2}$ July 17, after which they were observed less regularly. We found none breeding though we have downy young taken by Horsbrough at Mirror Lake, where he found large numbers of them in 1915. At Camp 11, July 27, Young collected a juvenile in an emaciated and starving condition, the only one seen there. From the remains found in the Duck Hawk nests we examined it was evident that Franklin's Gull is a favorable prey of that bird.

9. Larus sp. LARge GulL.- Horsbrough received a report of Herring Gulls, L. argentatus, that formerly bred on Buffalo Lake, but does not personally substantiate it further than by recording the presence of a pair there June 2, 1914. These records may refer to the California Gull, $L$. californicus, or even $L$. delawarensis.

10. Sterna sp. Tern.- At the Pump House Camp 4 near Nevis, July 8, terns were seen but not taken and their identity, whether Common or Forster's, is problematical. Horsbrough records the Common Tern as breeding near Alix but does not mention Forster's.

11.* Hydrochelidon nigra. BLACK TERN.-A few seen about small lakes at Camp 1 and again at Tolman's Ferry. We have downy young taken by Horsbrough at Alix, 1915. He found them breeding commonly at Buffalo Lake.

12. Phalacrocorax auritus. Double-Crested Cormorant.-Reported by Dippie at Buffalo Lake (1896?). Horsbrough mentions a bird, provisionally referred to this species, seen there May 20,1915 , and repeats reports of its breeding near Edmonton.

13. Pelecanus erythrorhynchos. White Pelican.-Though we saw no Pelicans we heard of them from several sources and Charles Sternberg reported seeing one at his camp on the Little Sandhill Creek, June 24.

14. Mergus sp. Merganser.- One was seen between Tolman's Ferry and Drumheller July 13. It was a female or juvenile and its species could not be determined.

15.* Anas platyrhynchos. MalLARD.-Quite common breeder on sloughs and ponds of the upper prairie level but less often seen on the river itself. Local residents near Red Deer speak with disdain of the locally 
raised "green heads" saying that the migrants that come in the fall are a much finer race of birds and easily recognizable by their superior size.

16.* Chaulelasmus streperus. Gadwall. - An adult and brood of newly hatched young seen and four of the latter collected between Camps 4 and 5, July 9. Dippie found it common on Buffalo Lake in 1896 and Horsbrough reports nests in 1914.

17.* Mareca americana. Batdpate.- At least two pairs observed on Brock's Lake near Camp 1, and a male collected, June 28. Horsbrough noted it near Alix and records nests at Buffalo Lake.

18.* Nettion carolinense. Green-winged Teal-Common and with young on some of the smallest sloughs on the prairie level but not often seen on the river itself. The only specimens obtained were flying juveniles at Camp 11, August 15 and 23 where Young reported them as not common.

19.* Querquedula discors. Blue-winged Teal.- Common on the lakes and sloughs on the prairie level but not seen often in the river valley. Specimens taken at Camps 1 and 11 August 24.

20.* Spatula clypeata. Shoveller.-Only seen at Camp 11 on the Little Sandhill Creek, August 17 and 18 when specimens were taken.

21.* Dafila acuta. Pintail. - This species did not seem to be very common. A female was seen swimming in the river between Tolman Ferry and Drumheller and acted as if it had young nearby. Young saw one large flock near the Little Sandhill Creek and took specimens of juvenile birds August 3 and 4. We have another specimen taken by Horsbrough at Buffalo Lake, May 1915, who records nests at Buffalo Lake and vicinity.

22.* Marila marila. Greater Scaup. - Though we did not specifically identify Greater Scaups we have one taken by Horsbrough, October 1915, at Alix, who reports nests at Buffalo Lake.

23.* Marila affinis. Lesser Scaup.- Numbers of Scaups were seen on the ponds on the prairie level near Camp 1 and near Nevis. Most seen were males. The few females seen acted as if they had nests nearby but none were found. Our only specimen was taken at Camp 1 and is of this species. The Lesser Scaup is not mentioned by Horsbrough.

24.* Marila valisineria. CANvas-BACK.- Two downy young in our collections taken by Horsbrough June 1914 at Buffalo Lake, who records several nests.

25.* Clangula clangula. American Golden-EYe.- The commonest duck on the upper river but not seen below Tolman's Ferry. The absence of the Golden-eye on the lower river is probably due to the lack of large timber supplying nesting holes. Most of the birds seen were females and it seems probable that the sexes separate before reproductive duties are finished. We surmise that the males might be found in numbers on the larger lakes in the vicinity. None were seen closely enough to detect Barrow's Golden-eye, though they were looked for carefully, and Horsbrough does not mention it. Our only adult specimen is a female and an undoubted American Golden-eye. Several broods of young were met with on the 
river and on Brock's Lake near Camp 1. Near the latter place we were shown a hollow tree where the species was said to have nested. At Camp 4 near Nevis is a pump house supplying water to the railroad some several miles away. The engineer in charge told us that ducks frequently entered the attic of his dwelling quarters through an open stovepipe hole and made considerable scratching noise overhead. I climbed up into the space through a man-hole but saw no indication of a nest. Without doubt these must have been Golden-eyes that were attracted to the place but did not find it satisfactory. Our specimens include representatives of two downy broods and one adult taken on Brock's Lake, Camp 1, June 28 and downy young above Nevis, July 6.

26.* Charitonetta albeola. Bufflehead.- Two females with small broods were seen on Brock's Lake near Camp 1 and afterwards occasionally as far as Ross's Ranch, July 9. Young saw two at Camp 11, Little Sandhill Creek, September 14. Our specimens consist of downy young, Camp 1, June 28. Also adults and downy young from Buffalo Lake, taken by Horsbrough, June 21 and May and September 1914, who records several nests.

27.* Oidemia deglandi. White-winged Scoter.- White-winged Scoters were common on the river as far down as Camp 5. There were quite a number on Brock's Lake near Camp 1 and singles and small flocks and pairs were encountered here and there flying up or down the river. Both sexes were present in about equal numbers and a female taken on Brock's Lake July 2 contained an egg nearly ready for deposition. The residents, however, do not know of their nesting in the neighborhood and were as curious as to where they nested as we were. We have another specimen from Buffalo Lake, June 1915, taken by Horsbrough, who says they nest late in the season.

28. Erismatura jamaicensis. RUDDY DUCK.-Dippie reports finding eggs at Buffalo Lake, June 14, 1896, and Horsbrough also records a nest there.

29. Chen hyperboreus. SNow Goose.- We heard of white geese being occasionally seen on the river but did not meet with any. Chas. Sternberg reports seeing one near the Little Sandhill Creek, June 2. This must have been a belated straggler. Horsbrough records both Greater and Lesser Snow Geese from Red Deer and Buffalo Lake respectively. He gives the length of the former as 27 inches but no further corroboration. He is probably mistaken in his diagnosis.

30.* Chen rossi. Ross Goose.- Two specimens in our collections taken by Horsbrough, Buffalo Lake, September 26 and October 10, 1914. He does not mention the species in his lists.

31.* Anser albifrons. White-Fronted Goose.-We have a specimen in the museum collection taken by Dippie on the Red Deer River, Sept. 12, 1896. Horsbrough reports a specimen in October 1915.

32.* Branta canadensis. Canada Goose.-A Mr. Krieger, upon whose land we camped at Camp 1, told us that geese used to nest on the 

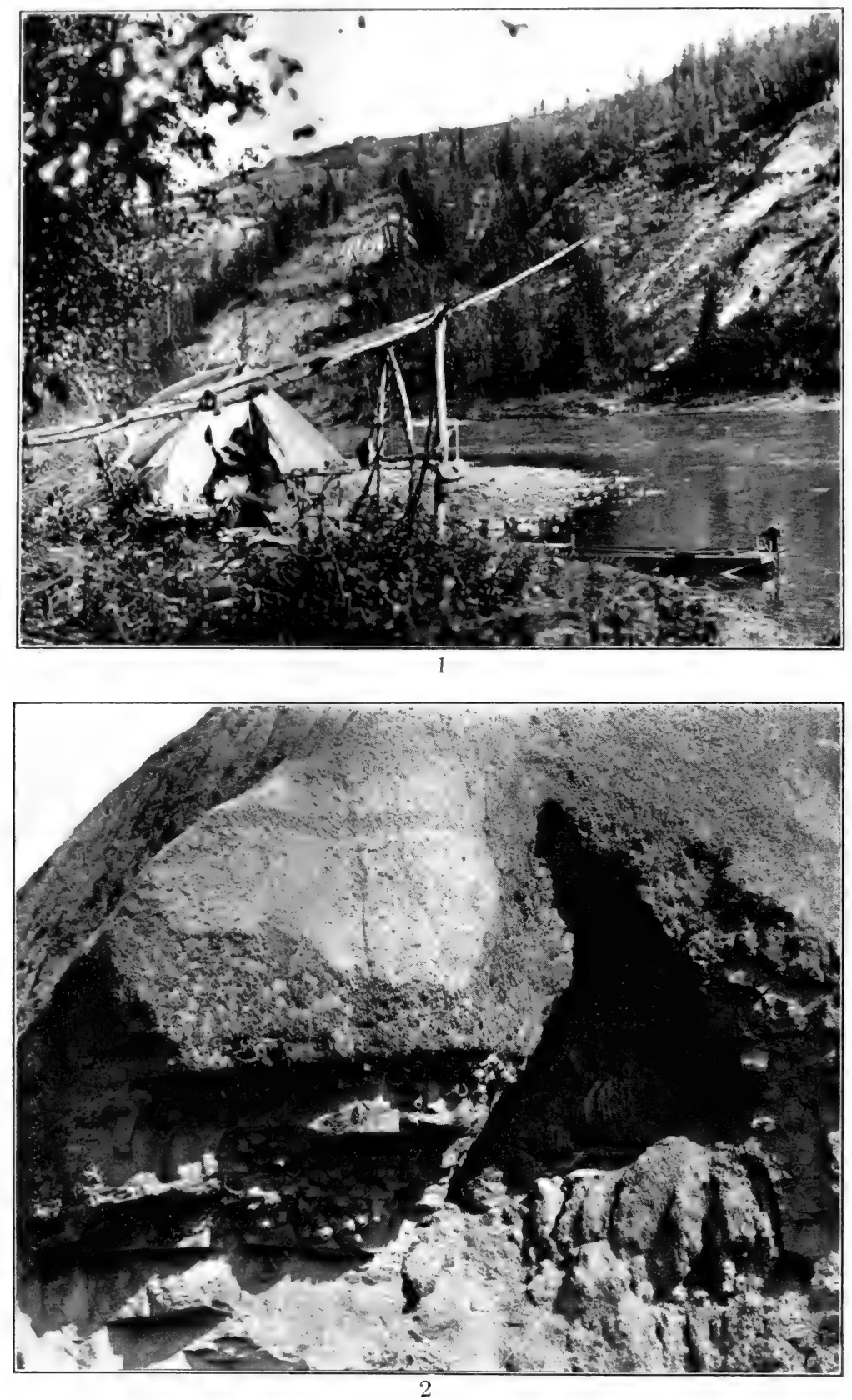

1. Camp 1, Near Red Deer, Alberta.

2. Nests of Cliff Swallows and Prairie Falcon near little Sandhill Creek, Alberta. 
clay banks in the immediate vicinity but have not done so for a number of years past. He further remarked that they are usually seen migrating high overhead and seldom come down into the river. Another Geological Survey party whom we met making a similar trip to ours under Dr. J. A. Allen of Edmonton, met two broods below Ross's Ranch. Between Camps 7 and 8 and 8 and 9 we met with nearly full grown families. When first seen they made for the shore along which they ran, trying to hide in the scanty bushes or in rock crevices. When routed out of these places or when they failed to find satisfactory concealment, they again took to the water and as none, not even the adults, could fly, they swam vigorously ahead of us, diving when we came too close. The female adult of one of these broods swam on ahead of us for several miles until the river widened enough to enable her to pass. The last seen of her she was paddling vigorously against the current endeavoring to rejoin her lost family, which were, by the way, sufficiently developed to be in little need of her care. Two specimens were taken, a nearly grown gosling and an adult female, July 17 and 18.

33. Olor columbianus (?). Swan.- Both Mr. Krieger and Mr. Brock at Camp 1 informed us that swans were occasionally seen passing over but know of none being taken. Horsbrough repeats reports of occasional flocks near Alix and Haunted Lakes in April.

34.* Botaurus lentiginosus. American Bittenn.- Mr. Brock near Camp 1, gave us a clear description of the Bittern in his neighborhood but it did not seem to be as common as would be expected amongst the numerous sloughs on the uplands and we did not note it until Young took a specimen August 22 at Camp 11 on the Little Sandhill Creek in the heart of the desert-like country. Horsbrough records nests at Buffalo Lake.

35. Ardea herodias. Great Blue Heron.-- Between Camps 3 and 4 and 9 and 10 single individuals were seen and followed from bend to bend for several miles before they circled back over the low bends and were lost. Young reports individuals in the vicinity of Camp 11, Little Sandhill Creek, August 14 and September 3. Horsbrough records only occasional birds and cites a couple of specimens.

36. Grus mexicana or canadensis. Crane.- Inquiries about Camp 1 brought forth reports that a few years ago three cranes, "exceedingly good eating," were killed in the neighborhood, but our informants were not otherwise familiar with the species. Probably this refers either to the Sandhill or the Little Brown Crane which should migrate through this section. Horsbrough mentions seeing a crane of undetermined species May 4 at Alix.

37.* Porzana carolina. SoRA RAIL.-Several Soras were seen in sloughs in the vicinity of Camp 1. Doubtless if we had worked adjoining ponds they would have been found throughout the country. Young took one near Camp 11 in a slough on the upper prairies near the Little Sandhill Creek.

38. Fulica americana. American Coot- - Not seen by us, but Horsbrough records it as the commonest breeding bird on Buffalo Lake. 
39. Steganopus tricolor. Wilson's Phalarope.- Recorded near Innesfail by Wm. Geary, Oologist, XIV, 1897, p. 24, but not seen by us. A few were noted by Horsbrough at Alix, Buffalo Lake and Red Deer, and he found a nest at Alix.

40. Recurvirostra americana. American Avocet.- Horsborough records a few breeding birds about Buffalo Lake.

41. Gallinago delicata. Wilson's Snipe.-Heard in their love flights, but not seen, as far down the river as Nevis. Young saw several and took specimens in the vicinity of Camp 11 on the Little Sandhill Creek, August 16. Horsbrough records nests at Buffalo Lake.

42. Macrorhamphus griseus. DowITcher.- Horsbrough records one taken at Buffalo Lake, August 22, referring it, probably incorrectly, to the western race, $M . g$. scolopaceus.

43. Pisobia minutilla. LEast SANDPIPER.-July 8 at Camp 4 near Nevis six small waders were observed flying by but under circumstances that precluded specific identification. From the date they might as well have been late spring Semipalmated as early fall Leasts. Horsbrough records the latter as migrants at Buffalo Lake.

44. Totanus melanoleucus. Greater Yellow-Legs.- Horsbrough records the species and says it frequently occurs with the Lesser Yellow-legs throughout the season at Alix and Buffalo Lake.

45. Totanus flavipes. Lesser YelLOW-LEgs.-Dippie thought they were breeding at Buffalo Lake in July 1896 and Horsbrough mentions them incidentally as occurring with the Greater in the same locality.

46. Helodromas solitarius. Solitary SANDPIPER.-A pair were seen on a small pool in an old ox-bow channel of the river near Nevis, Camp 4, July 6-9. Their strong reluctance to leave the immediate neighborhood and general actions were presumptive evidence of their breeding. I suspected the presence of young but could not verify it.

46.* Catoptrophorus semipalmatus. WILLET. - Just below Steveville and on the last few miles of our trip we saw three Willets on a mud bar in the middle of the river and collected two of them. They were both juveniles and could not be subspecifically determined. Dippie found young of Buffalo Lake, July 4, 1895, and Horsbrough records a nest there May 20, 1915.

47. Bartramia longicauda. Upland Plover. - Near Camp 1 a bird that we supposed to be of this species was seen and heard though not plainly enough to make certain identification. Mr. Brock, a local farmer, told us that two snipe-like birds bred in the vicinity besides the Spotted Sandpiper; a small one nesting in the swamps which we supposed to be Wilson's Snipe and a larger one on the uplands, laying a remarkably large egg. The latter is a quite suggestive description of this species. Horsbrough records a pair at Buffalo Lake.

49.* Actitis macularia. SPOTTED SANDPIPER.-Common all along the river and breeding everywhere. One bird on being flushed from her eggs flew into adjoining bushes and climbed about them in most unwaderlike style while complaining at our intrusion. 
50. Numenius americanus. Long-BILled Curlew.- Both Chas. and Geo. Sternberg who have had several seasons' experience on the Red Deer River have spoken of Curlews occurring in the late summer or early fall. July 22, when leaving, as I drove into Millicent I saw two or three Curlew flying in the distance. I refer them to this species on general probabilities. Horsbrough reports a sight record for the Hudsonian Curlew for Buffalo Lake, May 25, 1915, but does not mention the Long-bill. In western Alberta, the Hudsonian is most improbable.

51. Charadrius dominicus. Golden Plover.- Horsbrough records two specimens sent him from Buffalo Lake, Oct. 11, 1916.

52.* Oxyechus vociferus. Killdeer. - Not seen until August 23 at Camp 11, on the Little Sandhill Creek, where Young collected a single specimen from five seen. We have one downy young taken at Alix June 1915 by Horsbrough, who reports them common.

53. Perdix perdix. Hungarian Partridge.- Horsbrough was informed that this species was introduced near Alix in 1909, but failed to survive to date (1914).

54.* Bonasa umbellus. Ruffed Grouse.- Said to have been very common about Camp 1, a few years ago but now scarce. Though we found much excellent ground we met none in this neighborhood and only occasional ones elsewhere. The same agents that practically exterminated the Sharp-tails doubtless decimated this species. See that species for further discussion. At Camp 3 we saw and took one specimen; another was heard drumming at Camp 4 near Nevis. A brood of half grown young was met between Camps 5 and 6 and a single bird below Drumheller. Besides this specimen we have three birds from Ramsey and three from Morrin, taken by George Sternberg in 1915 and 1916. Of these but two birds are typical umbelloides, two cannot be distinguished from eastern togata, and the remainder are intermediate. $B . u$. umbelloides as it occurs on the Canadian prairies is a most unstable race and there is little satisfaction in attempting subspecific identification of individuals in these districts. The area of overlapping of the two races is very wide indeed. Horsbrough refers the local form to togata but has probably not compared specimens.

55. Tympanuchus americanus. Prairie Chicken.- I have had the pleasure of examining a specimen of this species taken by Mr. Horsbrough in the vicinity of Red Deer Dec. 26, 1914, as he records. As it was unknown to local shooters it appears that this is the first specimen of the species for this locality and may be the forerunner of a permanent intrusion.

56.* Pediœcetes phasianellus. Sharp-tailed Grouse. - This is the "prairie chicken," so called, of the Prairie Provinces, and as such is well known. They were said to have been exceedingly numerous on the Red Deer a few years ago but are very scarce now. Though we covered much ground where they were said to have been plentiful we saw none until late in July when Young collected four July 27 to September 13, in the neighborhood of the Little Sandhill Creek. We spoke to several residents 
who were familiar with them and their tales tallied closely. First there were great numbers of the birds and then they disappeared suddenly and without apparent cause. Coincidently numbers of "large gray hawks" and "big owls" appeared in the late fall and winter. Had the disappearance been principally due to overshooting, some birds would have been overlooked in the more out of the way localities; but, while the common report was that there had been little if any shooting on many parts of the river valley, the scarcity was general and we did not see a bird except as above. Correlated with the appearance of the raptores and the disappearance of the grouse of all kinds was the disappearance of the rabbits. It was the same story wherever we were in 1917: Shoal Lake, Manitoba; here on the Red Deer River; in British Columbia at Hazelton, and in Jasper Park, Alberta. In the last named place at least, overshooting cannot be blamed for the scarcity of grouse, as there is no shooting allowed there, and such small amount of poaching as might have taken place could not possibly have accounted for the almost total absence of birds. Also the widely scattered localities, practically all of central and western Canada, though perhaps less so in the mountains where heavy timber gives good cover, is suggestive of other causes than local shooting. I think it is evident that the occurrence of the well known rabbit disease that periodically decimates these rodents deprived the large raptores of their usual food and forced them to invade southern sections in unusual numbers and turn their attention to grouse. The Ruffed Grouse, living in the heavier timber where cover is better, suffered less than the more open country species. Without doubt when their usual food supply, the rabbit, is cut off, the large raptores constitute a serious destructive influence. It is an interesting study in the correlation of species and complicates the subject of game protection. All that seems possible to do under the circumstances is to encourage the killing of the large winter raptores, yet if this is carried too far the rabbit pests are likely to increase in normal years to a dangerous extent and in the present state of misinformation the ordinary farmer and shooter are likely to involve in destruction the useful species of Buteo and Archibuteo, birds that the prairie provinces cannot well spare. I will discuss them and their effects under the subject of Red-tail Hawk. Horsbrough refers his specimens to campestris, which is the geographical probability. The condition of plumage makes me unwilling to pronounce upon the subspecies.

57.* Zenaidura macroura. MoURNing Dove.- Not very common. We heard of a pair breeding near Camp 1. One was heard the morning of July 10 at Ross's Ranch and another at Drumheller the 14th. One was noted the 18th above Steveville and one taken the next day between that village and Camp 11. Horsbrough records a single specimen from Buffalo Lake.

58.* Cathartes aura. Turkey Buzzard.- We saw the first Turkey Buzzards shortly after we entered the real Bad-lands above Camp 5, Ross's: Ranch. From then on several or more were noted daily. At Camp 11 
on the Little Sandhill we saw aggregations of a dozen to twenty a number of times. Specimens taken at this camp August 20 and September 4. Horsbrough does not mention the species about Alix or Red Deer.

59.* Circus hudsonicus. Marsh Hawk.- Occasional Marsh Hawks were seen from Camps 1 to 4 but were not common. About fifteen miles above Steveville a number of juveniles were seen, probably an original family not yet separated. After I left Camp $11 \mathrm{Mr}$. Young reports that Marsh Hawks became common. One day he saw a female carrying a Flicker for about a mile and a quarter when she dropped it to two young. On approaching and driving them away he found the Flicker still alive. Specimens taken August 6 and 10.

60.* Accipiter velox. SHARP-ShINNed Hawk.- Not very common as we descended the river, though Young says they were numerous after the middle of September at Camp 11, on the Little Sandhill Creek, where he observed them teasing Pigeon Hawks. We found a nest with five newly hatched young near Camp 1, June 25. It was in a spruce tree about twelve feet from the ground. These were taken, also several at Camp 11 on the Little Sandhill, August 27 to September 7. We also have an October specimen from Alix taken by Horsbrough, who also records nests at Red Deer.

61*. Astur atricapillus. American Goshawk.- Between Camps 5 and 6, July 11, we saw a Goshawk cross the river ahead of us. Another was seen several times at Camp 8, near Rosedale Mines, and July 16 its nest containing three large downy young was found. It was about twenty feet up in a cottonwood in a slightly open spot in the bush. One was seen at Camp 11 on the Little Sandhill Creek, by Young, July 30. Besides the adult female and young above noted we have October and November specimens from Alix, taken by Horsbrough, and Mr. Edward Arnold informs me he has a set of eggs collected near Red Deer.

62.* Buteo borealis. RED-TAILed HAwK.-The most abundant Hawk on the river. It was seldom that one or more were not in sight and its nests dotted the larger trees every quarter of a mile or so to near Steveville. Near that village they grew fewer and finally disappeared and none were seen a few miles below at Camp 11 on the Little Sandhill Creek, in the midst of desert-like conditions. An accurate estimation of their numbers was very difficult owing to the presence of Swainson's Hawks from which it was usually most difficult to distinguish them except in most characteristic plumages. They were not excessively wary and a fine series of both adults and nestlings in various stages was obtained; the young usually with at least one parent taken and sometimes both. Of the birds seen there was a great variety of plumage and colorations, all the way from solidly dark to very light, faded specimens. The dark extremes were rather the least common and, either apparently or actually, more wary, for in spite of serious endeavor we were unable to obtain them. Several were shot, but falling off on a long slant they were lost in dense bush and could not be found. There is therefore still some doubt as to the 
identity of many of these birds and many may have been Swainson's instead of Red-tails. In all twenty-two specimens were taken. Of these, except for a very faint to pronounced barring of the tail, there is no constant character to separate them from eastern borealis. They average slightly darker on the under-parts but at least two birds are lighter here than typical eastern birds while several are indistinguishable in this respect. Many of the tails are very light, but new incoming plumage of richer coloration indicates that this is due to the bleaching power of the bright prairie sun and is an acquired and not an inherent character. Fading however does not account for all the lightness, as in some cases the feathers are mottled or suffused with white from the shaft outward. While this culminates in a female taken July 9 , the half grown offspring of the same bird has a dark tail similar to eastern juveniles, while all other juveniles having enough tail to judge from, show appreciable amounts of intermixed red such as is not seen in eastern birds.

I was in hopes that we would find krideri occupying this desert-like country but was disappointed, as we procured nothing that could not be attributed to calurus. One interesting point observed was that like usually mated with like, a light bird generally had a similarly colored mate and vice versa. Only in one case did we definitely discover a very dark bird paired with a light one. We obtained the three young of this pair and while they are hardly sufficiently fledged to accurately determine the characters they would finally exhibit, they show considerable difference in color. One tends towards an almost uniformly dark bird while the other two have plain indications of cream colored breasts and throats. It is evident therefore that the darkness of plumage is a congenital condition and not assumed with age; also that there is often a large amount of red in the tails of many juvenile birds such as is never (?) shown in eastern specimens of comparable age.

Naturally the abdomens of all the adults taken in the midst of the breeding season were bare; the skin was thickened and rugose, covered with dry, horny, scab-like plates that peeled off while skinning, and now that incubation was over, seemed ready to shed naturally before the incoming down of the midsummer moult. In addition to this, however, the throats were similarly affected. The throat feathers were ragged, worn and thin, whilst the skin between was excessively warty, the prominences tending to clear yellow in color and similar in appearance to the wattles of gallinaceous birds. It suggests that the throat is used in incubation as well as the abdomen.

The value of these large Buteos to the farmers of the prairie provinces is incalculable. This applies equally to Swainson's Hawk and the Ferruginous Roughleg. The country is infested with gophers, mostly Richardson's Spermophile in the section we visited, but Franklin's and the 13-lined were also present. Upon these the large hawks seem to feed almost entirely and their great number must be a powerful check upon them. However, 

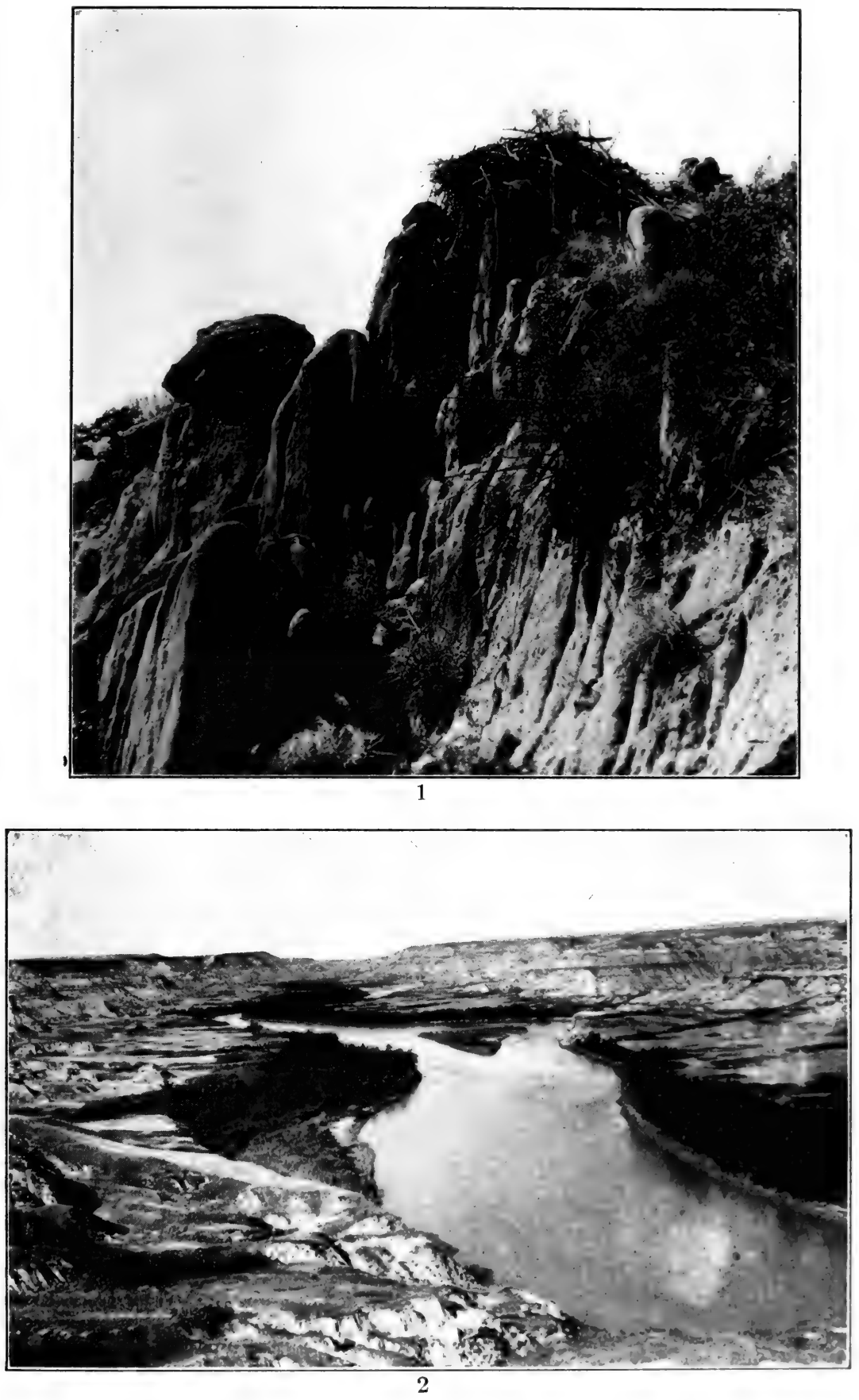

1. Nest of Ferruginous Rough-leg, below Nevis.

2. Red Deer River near Nevis, Alberta. 

this forms the subject of a separate publication, ${ }^{1}$ and calls for no further treatment here.

63.* Buteo swainsoni. Swarnson's Hawk.- Much that has been said of the previous species especially as to food, can be applied to this. Through the upper part of our course down as far as Camp 4, near Nevis, it seemed less numerous than the Red-tails; below that point it was about equal to them, disappearing with them at the entrance to the desert-like lower bad lands. Owing to the great variety of plumage of these two large Hawks it was in most cases practically impossible to distinguish between them except when in most characteristic plumage. Usually a dark breast band indicates Swainson's Hawk but we saw many variations that made us doubt the absolute reliability of even this character. On the whole, I suspect that the dark phase was slightly more common in swainsoni than in borealis. The commonest type of coloration had such a breast band but they ran through a redder type with less conspicuous breast band to a nearly black bird on one hand and to light plumages similar to normal juvenile eastern Red-tails. We took twelve specimens in all including. downy young. In nesting there was little difference that we observed, between these and Red-tails, though they were perhaps more prone to. choose smaller isolated trees standing in the open, a location we did not. see used by borealis at all.

64. Archibuteo lagopus. American Roughlegged Hawk.Horsbrough reports a few specimens on fall migration dates. Older literature includes nesting records for this and adjoining sections, but it is problematical whether they do not refer to the next species.

65.* Archibuteo ferrugineus. Ferruginous Rough-Leg.- Though we recognized no Rough-legs as such on the upper river or before we passed Camp 4, near Nevis, the residents about Camp 1 spoke of "Chap Hawks" so called from the feathering of the legs. Just above Camp 4 in the top of a cottonwood we saw a very large old nest that aroused our curiosity and which we later attributed to this species. Below Nevis we had our first. view of the species and from thence on it was very common, nesting on the tops of pinnacles and shelves of the bare eroded exposures and occasionally in trees. The nests were immense masses of coarse sticks and seemed to be added to and used year after year. Some nests seen about Camp 11 on the Little Sandhill Creek seemed to have been occupied for many years. One built upon a salient buttress of a cliff had increased with annual additions until it formed a mass of material twelve or fifteen feet high. The lower masses of the nest were rotten and merged into the original clay foundation whilst it grew fresher towards the top until the final layer was of this year's construction,- mostly sage-brush roots. In a little hollow adjacent to such a nest we found an accumulation of over a bushel of dried

1 The Hawks of the Canadian Prairie Provinces, in their Relation to Agriculture, by P. A. Taverner. Museum Bull. No. 28, Biol. Series No. 7, Geological Survey, Dept. of Mines, Ottawa, Aug. 1918. 
bones, and scraps of gophers that had been devoured by successive generations of young Rough-legs. The first nest we found contained three nearly fledged young and was on the top of a pinnacle on a deeply eroded exposure some 150 feet up and overlooking the river at a distance of about a quarter of a mile. In clambering about to get the properly lighted view for a photograph the young became alarmed and started out on their first flight, continuing until they dropped into the river below. One alighted near the margin and scrambled ashore but the other two drifted down and last seen were caught in the rapids below and drawn under and out of sight.

The coloration of these birds was remarkably constant. Most were of the light type, pure white below and with ruddy barred legs. Dark individuals were uncommon and we took only one specimen. This is a completely dark individual, a juvenile, and both parents were seen. One was of normal light coloration and the other all dark. Another juvenile similar to the one taken accompanied the family. We have five specimens of our own taking besides twelve more taken by Geo. Sternberg near Ramsey and Morrin in 1915 and 1916. Of these a brood of three taken June 26 is composed of one all black specimen and two that are evidently developing into the normally light-colored form. It is evident that, like the Western Red-tail, age has nothing to do with the darkness of coloration in this species.

66. Aquila chrysaetos. GoLden EAgLe.- Horsbrough records fall and winter specimens from the vicinity of Red Deer.

67. Haliaëtus leucocephalus. Batd Eagle.-Single Bald Eagles were seen between Camps 5 and 6 and 9 and 10. They were white-headed adults and easily identified. Horsbrough reports several specimens and gives a breeding record for the Buffalo Lake vicinity.

68. Falco rusticolus. Gyrfalcon.- Under the heading of Gray Gyrfalcon, F.r. rusticolus, Horsbrough records the capture of a specimen at Camrose, Oct. 1915, and mentions another taken about the same time.

69.* Falco mexicanus. Prairie Falcon.-Amidst the maze of gullies, pinnacles and strangely eroded hill shapes a short distance back from the river at Camp 11 on the Little Sandhill Creek we met a number of these birds. In all but color they are so like Duck Hawks that at a distance we confidently ascribed them to that species. At least two pairs had raised their broods near the camp and the nests were pointed out to us by Chas. Sternberg, who had marked them down before we arrived. Though in action and general habit similar to peregrinus the nests we saw were essentially different. In the first place they were rather solidly built structures of sticks or dead sage-brush roots; secondly they were in small natural caves of rather pronounced character, and finally they were at a considerable distance from the water, the immediate presence of which seems to be a necessity for the nesting site of the Duck Hawk. When we arrived on the scene the young had left the nest but a short time and were still in the vicinity and while full-fledged and apparently strong on the wing, they were under parental care. Between July 20 and August 31 
eight specimens were secured including both adults and juveniles. The latter differ from the former in being more creamy yellow. After identifying these birds we realized that we had met them before on the river but had thought them to be light plumaged Duck Hawks. They were usually seen bathing in the shallows of the river shore. At least two were seen between Camp 8 and 9 and one just above Steveville; all in arid country.

70*. Falco peregrinus. DUGK HAwK.-Though several of the birds we ascribed to this species during the last days of our trip were probably Prairie Falcons, a number previously observed were Duck Hawks. Friends about Camp 1 spoke of what they called Stone Hawks that nested on the adjacent cliffs, and one morning from our tent we saw a Duck Hawk feinting or making actual attacks on a Red-tail along the high cliffs across the river. The latter hastily took refuge in a tree-top and assumed the defensive while the Duck Hawk circled about chattering loudly and making frequent dashes at it, though as far as we could see no blows actually struck home. Shortly the falcon retired to an observation point on the cliff near by and waited, but at the first movement of the Buteo, returned to the attack and again drove it into a tree-top. It was half an hour or more before the Red-tail was allowed to slip away on its business. Just above Camp 2, and it was this that largely decided our stop, we discovered what was probably the same bird. It flew about us screaming loudly and was much disturbed at our presence. Parts of the cliff were liberally sprinkled with excrement and we were confident that a nest was nearby. The next day's careful search, however, failed to reveal it and upon collection the bird itself proved to be a non-breeding female. As when first seen it had one primary feather shaft broken as if by a shot we concluded that its mate had been killed and it having been unable to find another in time for breeding, still lingered and took a proprietory interest in the site of its old eyrie. Between Camps 5 and 6 a nest was found containing three downy young and with both parents in evidence. We collected one of the nestlings. A few miles below this nest another was found containing four nearly grown young and one parent present. In endeavoring to get a photograph of nest and young the better grown nestling took fright and left the nest. It flew up the river for nearly a quarter of a mile and finally came down in the river but soon scrambled ashore where we added it to our collection. Both these nests were on ledges on cliffs overlooking the river. In fact every Duck Hawk nest I have so far seen has been overlooking water and usually with water washing the base of the cliff upon which it was situated. Little or no nesting material was used and the eggs were laid upon the bare shelf. About them were scattered remains of various birds, the most conspicuous among which were the wing feathers of Franklin's Gull which from this evidence seem to be the favorite quarry of the Duck Hawks of this section in the nesting season. There were no indications of mammal remains and I conclude that this noble bird prefers feathered to furred game.

71.* Falco columbarius. Pigeon Hawk.- This species was one of 
the agreeable surprises of the trip. Throughout our descent of the river a close watch was taken for the species as it was hoped that Richardson's Merlin would be found. Birds were seen at a distance at Tolman's Ferry and Drumheller that were ascribed to this species but either the distance was too great or else the glimpse too fleeting to make positive determination, so up to the time of my leaving from Camp 11 we had no satisfactory record of the species. Shortly after I left Young began to find them quite numerous and to September 20, thirteen were taken. Of these but one was true $F$.c. columbarius, the remainder including 4 adult and 6 juvenile males and 2 juvenile females being typical richardsoni. We have also a male and female taken in June, in Cypress Hills, Saskatchewan; two more, probably an original pair from Edmonton taken by Spreadborough in May and a female with two downy young taken by Dippie near Calgary. It can be seen that in all we have a very good series of these birds, yet amongst them I can not see the slightest tendeney towards columbarius and am strongly inclined to regard richardsonii as a true species bearing the same relation to columbarius as Falco mexicanus does to $F$. peregrinus. The oft repeated statements copied from earlier descriptions inferring that this is practically a single plumaged species are certainly incorrect. Males are distinct from females and adults from juveniles; and all are easily separated from columbarius in any plumage.

72.* Falco sparverius. American Sparrow HaWk.-This species was not very common on the upper reaches of the river but as we descended we found them more and more numerous until at Camp 5, Ross's Ranch, there were at least four nests within three minutes' walk of our tent, and below, every suitable stub along the banks contained a nest. We noted them several times essaying the role of Kingbird and badgering large hawks that intruded upon their privacy.

73. Pandion haliaëtus. Osprey.-At Camp 1, just below Red Deer, I saw a bird that, at the time, I was confident was this species but not meeting it again I had removed it from the list of verified species. However, Horsbrough reports information of a pair that, up to a few years ago, nested at Pine Lake some twenty-five miles southwest of Red Deer, the birds being last seen there April 26, 1915.

74.* Asio wilsonianus. LONG-EARED OwL.- Not noted by us but we have specimens taken by Geo. Sternberg at Morrin, October 1 and 8, 1916, and at Alix, September and October, 1914, by Horsbrough who records a nest at Buffalo Lake.

75.* Asio flammeus. Short-eared OwL.- Young took one on the upper prairie level near Camp 11, on the Little Sandhill Creek, September 5. Besides this we have one from Alix, October 1914, taken by Horsbrough who also records a nest at Buffalo Lake.

76. Scotiaptex nebulosa. Great Gray OwL.-According to W. Raine, Dippie secured a set of eggs in the Red Deer District, probably about 1896. This likely remains the extreme southern breeding record for the species. 
77.* Cryptoglaux acadica. SAw-whet OwL.-We have one specimen in our collection from Alix, December 1914, taken by Horsbrough.

78.* Bubo virginianus. Great Horned OWL. - Nearly every one who supplied us with information spoke of the large numbers of Big Horned Owls present the previous winter. I am convinced that these were forced out of their usual winter haunts by the failure of the rabbit supply and are largely responsible for the dearth of Grouse of all kinds this year in the western provinces.

Just below Camp 8 near the Rosedale Mines we collected an adult male and a juvenile, probably its offspring. None were seen again until Young took an adult at Camp 11, on the Little Sandhill Creek, August 4. Besides these we have the following specimens from adjoining localities, three birds from Morrin and Sonema June 14 and September 24 and 25, 1915 and 1916, also one bird from Red Deer, an old mounted specimen taken at unknown date some years ago. Of these the Sternberg specimens and the two breeding specimens taken below Camp 8 are well marked subarcticus. The Camp 11, Little Sandhill Creek, specimen I regard as pallescens as accepted by the A. O. U. or occidentalis as defined by Oberholser's revision of the species. The Red Deer specimen is different from either, being an extremely red bird similar in general to a specimen from the mouth of the Salmon River, B. C., identified as saturatus by H. C. Oberholser but much redder than it or than any other specimen in our collection. Geographically the only thing it can be reasonably ascribed to is saturatus as is so understood by the A. O. U. list or lagophonus of Oberholser. This is undoubtedly a migrant from the mountains. B.v. subarcticus seems to be the breeding form while pallescens can be regarded either as a straggler from further south or an intergrade. The exact determination of these many Horned Owl forms is very difficult and hardly satisfactory when too great exactness is insisted upon. In the museum is a set of two eggs taken near Red Deer by Dippie, April 10, 1896. Horsbrough records B. $v$. pallescens as the breeding form in his first list and subarcticus in his second. Probably all breeding birds should be included in the latter form.

79.* Surnia ulula. American Hawk OwL.-Though not seen by us we have specimens taken by Horsbrough at Alix October 19, 1914, and by Geo. Sternberg, October 17, 1916, at Morrin whilst Chapman in his Handbook cites a breeding record, Red Deer April 16, 18 (?) Horsbrough gives no breeding records but regards the species as common.

(To be concluded.) 




\title{
THE BIRDS OF THE RED DEER RIVER, ALBERTA.
}

\author{
BY P. A. TAVERNER. ${ }^{1}$ \\ (Continued from p. 21.)
}

SinCE the first part of this paper went to press, I am in receipt of a series of notes from F. L. Farley, now of Camrose but formerly of Red Deer. His observations extend from 1892 to 1906 at the former locality and from then to date at the latter. They consist chiefly of lists of spring arrivals but have been supplemented by further details in correspondence. I have also received some comments upon the list as published from J. H. Fleming. The pertinent new information is embodied in the following continuation and the Addenda at the end.

80. Ceryle alcyon. Belted Kingfisher.-We found the species rather scarce on the river. This is probably accounted for by the cloudiness of the water which hides the fish. One bird was seen near Camp 4 near Nevis and Young recorded two at Camp 11 at Little Sandhill Creek. We have three birds taken by Geo. Sternberg at Morrin, August and September, 1915. Horsbrough records the Kingfisher nesting at Red Deer and Farley notes it occasionally at Camrose.

81. Dryobates villosus. HAIRY WOODPECKER. - Not very common anywhere but more seen in the upper parts of the river in the wooded sections than lower down. Singles or pairs seen at camps 1, 4, 6 and $8 \frac{1}{2}$. Specimen from Camp 1 also one from Rumsey, September 24, 1915, taken by Geo. Sternberg and another from Buffalo Lake, November 9, 1914, by Horsbrough who reports nest at Sylvan Lake. I ascribe them all by their large size to leucomelas. One specimen in Fleming's collection lately examined by me overmeasures any $D . v$. leucomelas I have previously seen, having a wing $140 \mathrm{~mm}$. Our next largest specimen is but 132 .

82. Dryobates pubescens. DownY WooDPEcker.- Not seen by us but both Horsbrough and Farley report it as a common resident and a

1 Published by permission of the Geological Survey, Ottawa, Ont. 
Vol. ${ }_{1919}^{\text {XXVI] }}$ TAVERNER, Birds of Red Deer River, Alta.

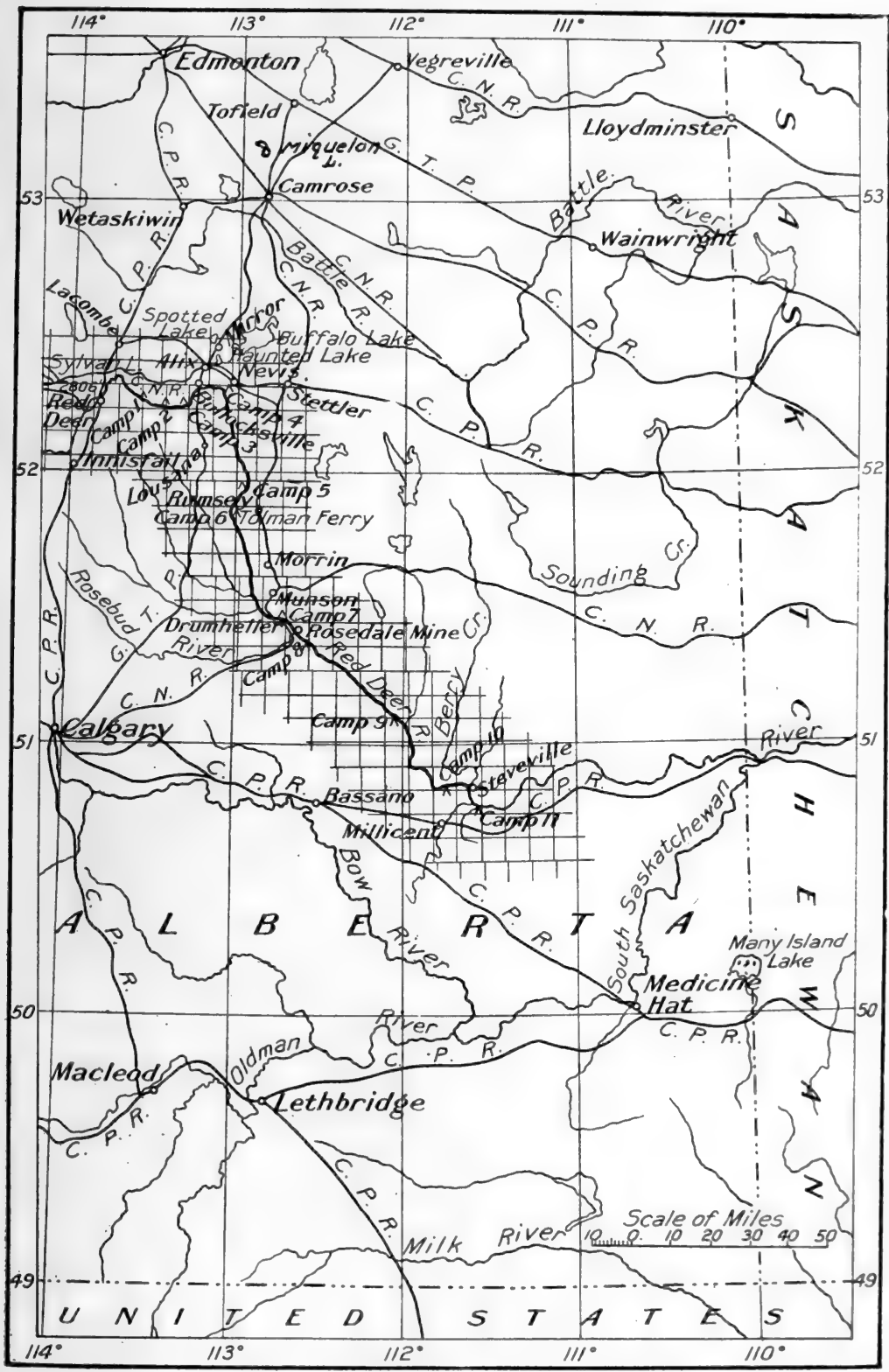


breeder. The former refers the local form to $D . p$. nelsoni, probably on geographical grounds for we have an Edmonton specimen, August 13, 1886, that has been identified by Oberholser as homorus. A female, Red Deer, April 19, 1916 in Fleming's collection agrees so closely with larger specimens from New Brunswick and eastern Ontario that I see no grounds for separating it from them and following Oberholser's determination of a B: nff bird August 13, 1891, ascribe it to D. p. medianus.

83. Picoides arcticus. Arctic Three-toed Woodpecker.- Under the subspecific designation, $P . a$. arcticus, Bangs lists five specimens, without date (collections of Wm. Brewster, and E. A. and O. Bangs) from Red Deer, Auk, XVII, 1900, -139.

84. Picoides americanus. American Three-toed Woodpecker.Mr. Farley reports taking a specimen in winter at Red Deer. He makes no subspecific determination. Geographically $P$. a. fasciatus is the probability.

85.* Sphyrapicus varius. Yellow-Bellied SAPSdCKeR.-Quite common on the upper parts of the river but as the country grew more arid it became scarcer and none were seen below Camp 5. One specimen, a female with black cap, Camp 1, June 30. Horsbrough records it breeding.

86. Phlœotomus pileatus. Pileated Woodpecker. - Farley say he knows of a few having been killed at Red Deer in winter.

87.* Colaptes auratus. Flicker.- Common throughout the river as ar as we travelled. Of the four birds taken by us and by Geo. Sternberg at Morrin but one is a pure auratus, the remaining specimens all having slight to strong traces of cafer blood indicated by the color of the large shafts, the graying of the throat or red in the black moustache. Near Camp 1, Young saw what he thought to be a red-shafted Flicker and doubtless birds that are more strongly cafer exist in the region, though auratus seems to be the predominating influence. Two birds, May 2 and July 17 Red Deer in Fleming's collection are pure auratus. Farley says he has seen nothing at either Red Deer or Camrose that he can ascribe to cafer. It would seem that the cafer influence is farther reaching on the lower than the upper parts of the river. Horsbrough on a guarded suggestion from Fleming refers his specimens to $C$. a. borealis.

88.* Chordeiles virginianus. NightнAwk.- Though rather rare at Camp 1, the Nighthawk became more abundant as we descended the river. None could be collected however, until Camp 11 was reached, where breeding birds were also noted. Our single bird, July 30 , is considerably lighter even than several hesperis as identified by Dr. Oberholser. I therefore tentatively refer it to sennetti. I suspect that this is the form of the arid southern sections, as a Red Deer Bird collected by Sternberg, June 4, 1915, is evidently virginianus, as is another from Banff determined by Oberholser.

89. Archilochus or Selasphorus. Hummingbird.- Mr. Farley reports having seen one Hummingbird at Red Deer the summer of 1892 . 
He thought it a Ruby-throat at the time, but this requires confirmation by specimens for confident acceptance.

90.* Tyrannus tyrannus. KingBird.-Rather scarce on the upper parts of the river. At Camp 1, we noted but a single bird, and until Camp 4 but occasional individuals were glimpsed in the distance. Below Camp 4, near Nevis, however, Kingbirds became common. The last one seen was September 7. Two specimens, Camps $4 \frac{1}{2}$ and 11.

91.* Tyrannus verticalis. Arkansas KingBird.-Only seen at Camp 11 after I left. Young says "Not as common as the Kingbird." Three taken July 31. Not listed by either Horsbrough or Farley. Probably an inhabitant of the more southern sections of the river.

92.* Sayornis phœbe. PheBe.- Not uncommon as far down the river as Camp 6, Tolman's Ferry, but not noted below. One specimen, Camp 2.

93.* Sayornis sayus. SAY's PнбBE.- One pair were nesting near the top of a cliff near Camp 2, and seen again the next day while en route. At Camp 6, Tolman's Ferry, Young found it nesting in the adjoining hills and took a specimen. From then on they were seen almost daily and at Camp 11, Little Sandhill Creek, they were quite common. It nests on small ledges on the cliff faces and seems rather more common in the arid than the humid country. Specimens from Camps 6, 8 and 11, the last being September 14. Not mentioned by either Farley or Horsbrough.

94. Nuttallornis borealis. Olive-Sided Flycatcher.-Farley reports this species at Red Deer, May 22, 1905.

95.* Myochanes richardsoni. Western Wood Pewee.-Wood Pewee-like notes were heard constantly about Camp 1, but the birds were so shy that one was collected with difficulty. The notes were much like those of our eastern Wood Pewee but different enough in quality to be distinctive. They were not noted often thereafter but from August 6 to 25, Young took several at Camp 11, on Little Sandhill Creek.

96.* Empidonax trailli. Traill's Flycatcher.- On the uplands about Camp 1, in the thickets adjoining sloughs, this species was recognized a number of times. Thereafter we were seldom in proper country for it. At Camp 11 on the Little Sandhill Creek, Young collected specimens, August 9 and 11, probably early migrants. Both are referable to E. t. alnorum. Farley lists it at Red Deer and Camrose.

97.* Empidonax minimus. LeAst Flycatcher. - Common all along the river. Specimens taken at Camps $3,3 \frac{1}{2}, 5$ and 11.

98.* Otocoris alpestris. Horned LARK.- We saw no Horned Larks until Camp 11 on the Little Sandhill Creek was reached, where Young reports that he found them common on the flats of the north side of the river feeding on wild buckwheat. Fourteen specimens were taken between July 26 and September 20 . These are all leucoloma as recognized by the A. O. U. or enthemia according to Oberholser and Ridgway.

99.* Pica pica. Magrie.- One of the pleasures of the trip was acquaintanceship with this bird. We heard of occasional Magpies being 
seen about Camp 1, but did not meet with them personally until between Camp 5 and 6 when we found a family party of partially fledged birds discussing the world and things in general in the Saskatoon bushes. "Chattering like a Magpie " hardly gives a clear idea of the performances. They keep it up continually in season and out, but the talk is deliberate rather than " chattering." They are never still for a minute and their curiosity is insatiable. Every morning our camp was the center of interest and conversation to a group of these long-tailed clowns, uniting the gravity of judges with the talkativeness of a debating society. At Camp 11 a nearby creek bed cut down some twelve feet below the general level' and dry and parched in the sun was the repository of our empty cans and table scraps. Magpies were always in attendance and no sooner had the falling can ceased its noisy rattling and come to rest than a "Pie" was on hand to glean what it might from its depths. They seemed to go in small companies, probably original families though perhaps in some cases more than one brood had joined together and haunted the brush in the wooded river edges or the low dense tangle on hill tops sailing from clump to clump and furtively following one another from cover to cover. Their nests were conspicuous objects in the heavier bush. Great oval masses of sticks four or five feet high and two or three feet through with the nest in the center reached by openings in opposite sides for ingress and egress. The fact that we invariably found them in the neighborhood or not more than a hundred yards or so from nests of Red-tail or Swainson's Hawks may or may not have a meaning; nor is it clear, if it is more than accidental, which - the "Pie" or the hawk - was first to choose the locality. Specimens were obtained at Camps $5 \frac{1}{2}$ and 11 while we have others from Rumsey and Morrin collected by Geo. Sternberg.

Farley, Horsbrough and Dr. George of Red Deer, all declare that this species is increasing. Farley writes,- " No one knew this bird ten years ago and for the past few years a month does not pass that some one does not ask about it. I think this about its limit line as I never saw or heard of one farther north than ten miles from Camrose."

100.* Cyanocitta cristata. BluE JAY.-Fairly common on the upper parts of the river but not seen below Camp 4, near Nevis. One specimen, Camp 1. Reported nesting by Horsbrough.

101. Periscreus canadensis. Canada JAY.-Spreadborough's hypothetical record of this species at Red Deer is substantiated by Farley who says he found two nests of the Canada Jay ten miles east of Red Deer, the eggs from which he sent to W. E. Saunders of London, Ont. According to Oberholser's determinations these birds should probably be referred to $P$. $c$. canadensis.

102. Corvus corax. Raven.-Farley says,-" The Raven is seen nearly every November at Red Deer. I have never seen them brought in except in early winter."

103.* Corvus brachyrhynchos. American Crow.-Only fairly common in the narrow parts of the valley where the river is in closer 
proximity to cultivation. Below, where the valley is wide, and more arid conditions prevail, it was but occasionally seen. Young reports, at Camp 11 on the Little Sandhill Creek after the middle of September, that they appeared in large flocks. The farmers about Camp 1 did not regard the crow as dangerous to crops but complained of the number of small chickens they kill and the duck nests they rob. Specimens from Camp

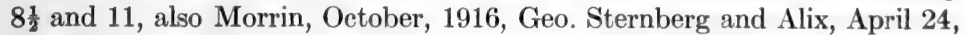
1914, Horsbrough. Amongst our prairie province specimens I can find little to substantiate the Western Crow, hesperis. The birds of smallest measurement in our collections come from Ottawa and Point Pelee, Ontario; Red Deer, Alberta; and Lillooet, British Columbia, whilst our largest specimens are from Ottawa and Indian Head, Saskatchewan. Even the averages from eastern and western Canadian specimens are too similar for the recognition of any subspecies. I therefore prefer to class these birds with the type form brachyrhynchos.

104.* Molothrus ater. CowBIRD.- Rather scarce. We saw but two at Camp 1. Young took a specimen at Camp 11 on the Little Sandhill Creek, August 2. We also have one bird from Morrin, July 1916, taken by Geo. Sternberg. The bird from Camp 11 is a juvenile but extraordinarily heavily striped below, almost as conspicuously so as a juvenile Red-wing. Above, every feather is bordered with sharp buffy edges. The Morrin bird is similar but does not depart from normal in so marked a degree. As these are both juveniles their measurements are not satisfactory for subspecific comparison. Examining our series of western Cowbird specimens I can only see that they average slightly larger than eastern ones. The bills are comparatively a little longer but the concave character shown by Grinnell as characteristic of artemisioe is not recognizable even though the sage brush Artemisia tridentata with which its range is supposed to coincide extends far north of here to the Peace River Valley. Without further data I can only regard these Red River birds as abnormal ater.

105. Xanthocephalus xanthocephalus. YelLOW-HEAded BLACKBIRD.- Not seen by us owing probably to the absence of extensive marshes in the localities visited. Geo. Sternberg reports having seen one at Camp 11 before our arrival. Mr. Farley lists it at Red Deer and Camrose.

106.* Agelaius phœniceus. Red-Winged Blackbird.- Not very common but occurring in most of the suitable localities visited by us. More common on the prairie level where sloughs are more numerous than in the valley. Specimens from Camp 1 and 4. After comparing these and other prairie specimens with eastern birds I can only say that there is a larger percentage of oversized birds amongst them than in the East. I can see no constant difference in the bills and hence am not justified in referring them to anything but phæniceus. Horsbrough refers his, probably on geographical considerations to $P$. a. fortis.

107.* Sturnella neglecta. Western Meadow Lark.-We did not find this bird very common in the river valley and not overly numerous 
upon the prairie levels when they were visited. Later in the season, Young reports that they were common at Camp 11 in early morning when they came down from the Prairie level to drink at the river. Specimens from Camp 1 and 11, also two Morrin birds, August and July, Geo. Sternberg.

108. Icterus galbula. Baltimone ORIOLE.- Horsbrough records the nesting of the Baltimore Oriole at Red Deer and Farley pronounces it common. Neither seem to be acquainted with Bullock's. In our collections are specimens of galbula from Edmonton and bullocki from Medicine Hat where, however, Spreadborough also noted the former. Possibly the division between the two occurs somewhere between the two cities and the Baltimore is the form at Red Deer.

109.* Icterus bullocki. Bullock's OrIOLE.-Only two orioles seen and thrse two of this species. Taken at Camp 11, Little Sandhill Creek, August 29.

110.* Euphagus carolinus. Rusty BLACKBIRD.-One specimen, Alix, Alberta, April 22, 1914, by Horsbrough who infers in his annotations that it is only a migrant at Red Deer though Farley reports it as with Brewer's,- " a very common spring and fall migrant and quite plentiful breeding along the streams in the willows." I was hardly prepared to regard this as a breeder in this locality.

111.* Euphagus cyanocephalus. BRewer's BLACKBIRD.-Generally distributed throughout the river valley but nowhere exceedingly common. Young noted a large migrant flock at Camp 11, Little Sandhill Creek, the middle of Septomber. Specimens, Camp 1 and 11. Farley reports it breeding along the streams in the willows.

$112^{*}$. Quiscalus quiscula. Crow BlackBIRD.- Only a few seen at Camp 1, about Brock's Lake where they were nesting in Flicker holes. One specimen, Camp 1, another Buffalo Lake, August, 1915.-Horsbrough. Regarded as common by all correspondents.

113. Hesperiphona vespertina. Evening Grosbeak.- Farley says, - "The Evening Grosbeak is not regular in winter. It comes for about a month about every other winter, always feeding on the seeds of the Manitoba Maple." Red Deer Specimens, May 6, in Fleming's collection.

114. Pinicola enucleator. Pine Grosbeak.-Farley says,- " Pine Grosbeaks are fairly common all winter especially along the rivers in the spruce,- never saw them after May 1." Horsbrough lists them under $P$. e. leucura on J. H. Fleming's determination based upon a bird with an imperfect bill. I have examined this bird but the subspecific characters are so faintly indicated in our comparative series that I prefer to withhold judgment upon the determination.

115.* Carpodacus purpureus. PurPle Finch.- Not seen on the upper river at all and at Camp 11, Little Sandhill Creek, only after I left. Young reports that beginning August 18, he noted one to five daily to September 7. He observes that they were feeding on the seeds of the black birch. One specimen, Camp 11, August 18. Listed by Farley as 
common at Red Deer though Horsbrough gives only individual records:

116.* Loxia curvirostra. American Crossbill.-One specimen taken at Camp 11, Little Sandhill Creek, July 21. It is a juvenile with clear skull but with the red beginning to replace the yellow plumage. About the face and throat is a powder deposit similar to that on a Jasper Park bird that was feeding upon woolly aphides suggesting that this bird was subsisting upon a similar diet. Farley regards it as common all winter, and I infer regular, but " never noted after May."

117. Leucosticte tephrocotis. Rosy Finch.-Farley says,-- "I have seen the Leucosticte in November around the coal mines in the Red Deer valley where you go under the C. P. R. bridge. They were the tamest birds I ever saw and I suppose had just blown down from the tops of the mountains." He later informed me that he sent a specimen to W. E. Saunders, London, Ont., who pronounced it Gray-crowned L. $t$. tephrecotis.

118. Acanthis linaria. REDPoll. - Both Horsbrough and Farley report Redpolls in winter. The former identifies them as $A$. l. linaria and the latter says he "cannot say that he has been sure of more than one kind," he thinks, " the smaller one."

119.* Astragalinus tristis. American Goldfinch. - Seen in limited numbers all along the river. At Camp 11, Little Sandhill Creek, Young reports large flocks feeding on the seeds of the wild sunflower Helianthis petiolaris in early September. One specimen from Camp 1 and four from Camp 11. All these birds are of a slightly deeper and richer yellow than eastern ones. The difference, however, is very little and only appreciable when numbers are massed together. I do not think that individual specimens can be recognized. In size there are more large birds in the western series, but the extremes in size, east and west, exhibit little, if any, difference. Under such circumstances I cannot see that it is worth while recognizing the Pale Goldfinch, pallidus in these specimens. Horsbrough refers his specimen to " $A$. t.tristis. Pale Goldfinch" (sic). With this conflict between scientific and vernacular terminology, it is left to surmise which he intends.

120.* Spinus pinus. Pine Siskin.-A small flock seen at Camp 3. One at Camp 11, Little Sandhill Creek, August 15 and 22. Specimens, Camp 3 and 11. Given as winter visitor by both Horsbrough and Farley.

121.* Calcarius lapponicus. Lapland Longspur. - Seen at Camp 11, Little Sandhill Creek, between September 10 and 15. Specimens, September, 13 and 15. Farley gives many April dates for both Red Deer and Camrose.

122.* Calcarius ornatus. Chestnut-collared Longspur.-One seen, July 26 at Camp 11, Little Sandhill Creek, becoming fairly common September 10 to 13 then no more until the 20th when two were noted. Specimens Camp 11, July 26 and September 13. Farley reports them very common in May and in autumn but does not remember them in summer. 
123.* Poccetes gramineus. Vesper Sparrow.- Rare along the river valley but common whenever we visited the upper levels. Young reports it common up on the prairie and along the creek beds at Camp 11, Little Sandhill Creek. Nine specimens from Camps 1, 6, 8 and 11. They are obviously referable to $P . g$. confinis.

124.* Passerculus sandwichensis. Savannah Sparrow.- Quite common in the more cultivated sections but scarce or absent over much of the river valley. At Camp 11, Little Sandhill Creek, very scarce at first, only two seen in August, but began to be numerous late in September. 13 specimens, Camps 1 and 11 . Two types of coloration are exhibited in these specimens. Those from Camp 1 are all yellow eyebrowed birds, while amongst those from Camp 11 occur yellow and white eyebrows. Until a detailed study is made of Canadian Savannah Sparrows I do not care to make subspecific determination. $P$. s. alaudinus is the generally accepted form in Canada west of Ontario.

125.* Passerherbulus lecontei. Leconte's Sparrow.-But one recognized near Camp 1, in a dry slough. Young found occasional scatered individuals at Camp 11, Little Sandhill Creek, two of which were in marshes on the upper levels, the remainder being in the desert lowlands. It is evident from the specimens obtained that the species has a distinct juvenile plumage composed of soft golden stripings quite different from the first winter plumage which is similar to that of the adult spring coloration. Specimens from Camp 1 and 11. Farley knows the species and does not regard it as rare.

126. Passerherbulus nelsoni. Nelson's Sharp-tail. - Farley reports shooting this species for identification and finding it quite common in the open country around large flat sloughs.

127.* Chondestes grammacus. LARK SParrow.-Fairly common at Camp 11, Little Sandhill Creek, not seen elsewhere or after August 17. Specimens from Camp 11. I am not prepared with eastern specimens to differentiate between the two races grammacus and strigatus. Neither Farley nor Horsbrough mentions this species at Red Deer and it probably does not occur there regularly.

128.* Zonotrichia leucophrys. WhITE-CROwned SparRow.- Not noted until September 3, Camp 11 on the Little Sandhill Creek. Young reports them quite common then along the river feeding on dogwood seeds and Buffalo berries. Four specimens Camp 11, September 3 to 12 . Only one of these is in high plumage. It is obviously $\boldsymbol{Z}$. l. gambeli and all are inferentially included under the same subspecies. Listed as a common migrant by Farley.

129.* Zonotrichia albicollis. WhITE-THROAted SPARROW.-Quite common and evidently breeding on the upper part of the river, but not noted below Camp 4 near Nevis, until they put in an appearance at Camp 11, on the Little Sandhill Creek, August 22, when Young met limited numbers with fair regularity. Specimens from Camp 1 and 11.

130. Spizella monticola. Tree Sparrow.- - Listed as a common 
migrant by Farley at Red Deer and Camrose. Horsbrough records spring birds under title of $S$. $m$. ochracea.

131.* Spizella passerina. ChIPPINg Sparrow.- Unexpectedly absent from the upper parts of the river. Young reported one at Camp 4 but it was not until we reached Camp 11 on the Little Sandhill Creek that we met them again. Here they were quite common and remained so until the first week in September. Four specimens from Camp 11, July 20, 27 and 28. I refer them to $S$. p. arizonce.

132. Spizella pallida. Clay-COlored Sparrow.- Common everywhere along the river,- the only generally common sparrow. Specimens from Camps 1, 5 and 11.

133.* Junco hyemalis. SuATE-COLORED JunCo.- Fairly common and breeding as far down the river as Camp 4, near Nevis. Below, they became less numerous and none were seen below Camp 6 at Tolman's Ferry, until the migrants came in September 17. Specimens from Camps 1 and 11 . These birds show no tendency towards either pink sides or red backs and can only be referred to $J$. $h$. hyemalis

134.* Melospiza melodia. Song Sparrow.-Common throughout the entire trip. 15 specimens from Camps 1, 2, 3, 4, 5, 6, 8 and 11; also one July 20, Morrin,- Geo. Sternberg. Though much more worn and hardly comparable with other material on hand, these specimens are just what would be expected from much abraded juddi. Specimens from Camps 5, 8 and 11 and Morrin are considerably darker than the others, reversing the expectation that light not dark birds would be found in the more arid sections. Horsbrough lists his specimens as $M$. m. melodia. It is not evident whether he has considered juddi or not.

135.* Melospiza lincolni. Lincoln's Sparrow.- Not seen until August 25 at Camp 11 on the Little Sandhill Creek. They gradually grew more common until September 5 when they became very numerous in open woods and low lands and especially so on the prairie level. One specimen from Camp 11. Though not mentioned by Horsbrough, Farley regards Lincoln's Sparrow as a not uncommon breeder at both Red Deer and Camrose, saying,- " It appears to be regularly distributed but not thickly. I can always depend on hearing at least one every few miles in scrubby country and have watched a pair all through the summer in the same brush so am sure they breed."

136. Melospiza georgiana. Swamp Sparnow.- Reported by Farley from Red Deer as not common.

137.* Passerella iliaca. Fox Sparrow.-Reported by W. E. Saunders at Red Deer in June 1906, in 'Catalogue Canadian Birds,'-J. and J. M. Macoun, 1909, not seen by us. Farley says,- "The Fox Sparrow is a regular breeder in localities. Have known several places where they breed regularly, - as many as a dozen pairs on a mile square. In such places their song is the commonest of any bird." These are probably $P$. $i$. iliaca.

138.* Pipilo maculatus. Spotted Towhef.- Towhees were not 
observed until we reached Camp 5, Ross's Ranch, where they suddenly became quite common, thus putting in an appearance with the first decidedly arid conditions. They remained common the rest of the trip. The spotted Towhee has a varied vocal repertoire. While many of its notes are strongly reminiscent of the Chewink, none are exactly similar and it has many peculiar to itself. The familiar Che-week was not heard but the "ya-ree-ee-e" song was quite recognizable with slight but obvious variation. Six specimens from Camps 5, 6, 8 and 11. Naturally all are referable to $P . m$. arcticus. Towhees are not mentioned by either Horsbrough or Farley. Probably this is another species whose limit is south of Red Deer.

139.* Zamelodia ludoviciana. Rose-breasted Grosbeak.-One seen and taken at Camp 1 but not noted again until August 19 and 20 at Camp 11 on the Little Sandhill Creek when singles were observed. Juveniles and females seem to differ from those of the Black-headed Grosbeak only in the absence of traces of lemon yellow on the under parts. The Camp 1 specimen is peculiar in having a large bright red throat patch in addition to the usual breast spot. I have seen indications or suggestion of this in other specimens but in none others examined has it been entire and pronounced. Specimens from Camps 1 and 11. Reported nesting at Red Deer by Horsbrough.

140.* Zamelodia melanocephala. Black-headed GrosbeaK.Only seen at Camp 11 during August where Young reports it as being not uncommon. Specimens from Camp 11, August 11. Not mentioned by any Red Deer correspondent, probably of more southern distribution.

141.* Piranga l udoviciana. Western Tanager.- Only a few seen by Young at Camp 11, on the Little Sandhill Creek the last of August and first of September. Specimens August 21 and 25. Dippie reports skins and eggs from Red Deer and Horsbrough records nests at the same place.

142. Progne subis. PurPle Martin.- Horsbrough records occasional birds between Mirror and Buffalo Lake and nests in rotten stumps near Sylvan Lake but says they are not common. Specimen in Fleming collection.

143.* Petrochelidon lunifrons. Cliff Swallow.- Very abundant along the whole river, nesting in large colonies under the overhangs of cliff ledges. In places the cliff face is covered solidly over many square yards with nests. Not all of these colonies are occupied, and I presume that they are used but a single season and that the colony seeks new location yearly until the old nests gradually weather away and make room for new ones. It was interesting to note that though many colonies seemed to be built in exposed situations, when rain came, all we observed remained dry while the surrounding cliff face was soaked with wet that would have instantly dissolved the frail clay structures. There is obviously more method in their choice of site than is evident on a casual survey. As it was, we noted many colonies that seemed to have been in situ for 
several years, illustrating the discrimination of their judgment. In one such colony I found old swallow nests doing new service for House Wrens that had filled them with sticks and were rearing families within them. Rather unexpectedly we found many occupied nests in the immediate vicinity of Duck Hawk and Prairie Falcon eyries. See antea plate opp. p. 11. We often found them plastered right up to and on the very ledges so occupied and the swallows coming and going without the slightest hesitation in the presence of the Falcons. So often did we observe this, that it suggested that such vicinities were matters of choice rather than the accident of indifference. Specimens from Camp 2 and 11, none seen after August 11.

144. Hirundo erythrogastra. Barn Swallow.- Not noted on the upper parts of the river but a few were seen at Camp 6, Tolman's Ferry. At Camp 11, Little Sandhill Creek, Young observed a few each day until September 25. Reported from Red Deer by both Horsbrough and Farley but apparently not common.

145. Iridoprocne bicolor. Tree Swallow.-But two individuals noted at Camp 1, July 1 and 2. Farley seems to regard it as common and Horsbrough records nests at Buffalo and Haunted Lakes.

148. Riparia riparia. BaNK Swallow.- Seen constantly all the way down the river and at Camp 11, Little Sandhill Creek, until the end of July after which none were noted. They nest in the many banks lining the river. As these are constantly caving in and sliding into the river, great numbers of birds and nests must be annually destroyed. They show less foresight in the choice of nesting sites than do the Cliff Swallows. Horsbrough records only a single nest and Farley refers to but a few. It probably keeps close to the river banks where it is not seen by the general observer.

147. Bombycilla garrula. Bohemian Waxwing.- Horsbrough records this species as - "During the summer this species was common throughout the Alix district." He records nests on the authority of Dr. George of Red Deer and Mr. Cook of Buffalo Lake. These observers seem perfectly familiar with the Cedar bird so this rather unexpected record can not be altogether disregarded on the grounds of confusion between similar appearing species.

148.* Bombycilla cedrorum. Cedar Waxwing.-Fairly common throughout the river. Specimens, Camp 11, July 20 and August 14.

149. Lanius borealis. Northern Shrike.-Farley notes the Northern Shrike at Camrose in November and December.

150.* Lanius ludovicianus. Loggerhead Shrike.- Only seen at Camp 11 where one or perhaps two families were reared and I took a female with accompanying young and later Young took a single adult female. Specimens, July 21 and 28 . Only one of these is subspecifically determinable, it has the extensive white rump typical of $L$. l. excubitorides. Farley gives spring dates for the species at both Red Deer and Camrose.

151.* Vireosylva olivacea. Red-Eyed Vireo.- Seen fairly con- 
stantly all the way down the river but less common below than above where the banks are more wooded. At Camp 11, Young did not meet it until August 20 nor after September 1; and never in any numbers. Specimens from Camps 1, 8 and 11.

152.* Vireosylva philadelphia. Philadelphia Vireo.- Taken at Camps 1 and 3 but not recognized again. At Camp 11, Young saw a few small vireos but no Philadelphias were recognized. At Camp 1, a male and female were taken June 30 and July 3 . The abdomens of both showed indications of incubations and doubtless it was an original pair of breeding birds. Horsbrough records a nest at Sylvan Lake he supposes to be of this species.

153.* Vireosylva gilva. Warbling Vireo.- Small Vireos were not common anywhere on the river. The only ones positively identified by capture proved to be Philadelphias until August 16 when Young took a Warbling at Camp 11 on the Little Sandhill Creek. Occasional specimens were seen that he took to be the same species until September 5. I refer this specimen to $V . g$. gilva.

154.* Lanivireo solitarius. Solitary Vireo.-One seen and collected at Camp 11, Little Sandhill Creek, and six were noted the same place, September 1.

155.* Mniotilta varia. Black and White Warbler.-Only seen at Camp 11, Little Sandhill Creek, between August 13 and September 1. Two specimens taken.

156.* Vermivora celata. Orange-Crowned Warbler.- One adult male taken at Camp 2. Its song was slightly reminiscent of a wren and I suspect it was nesting nearby. Occasional birds were seen and taken at Camp 11, Little Sandhill Creek, between August 25 and September 17. This specimen is colored light enough for $V$. c. orestera, its size is small for any race but $V$. c. lutescens, under which confliction of characters I prefer to leave its subspecific identity open, together with the four Camp 11 juveniles that accompany it.

157.* Vermivora peregrina. Tennessee WArbler.-Seen at Camp 1, where I suspected it was nesting but received no corroborative evidence other than season and its uneasy actions. Seen for a few days after the middle of August at Camp 11 on the Little Sandhill Creek. Specimens from Camp 1 and 11, August 13, 15 and 21. From Farley's notes this appears to be quite a common species at both Red Deer and Camrose, - at least in spring.

158.* Dendroica æstiva. Yellow WARBLer.- Not abundant but a few seen at nearly every camp. Not common at Camp 11, Little Sandhill Creek, except from August 9 to September 8 after which they decreased,

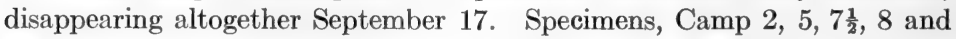
11.

159.* Dendroica coronata. Myrtle WARbler.-One seen at Camp 2 was the only one observed until August 23 after which they gradually increased in numbers during Young's stay. Specimens from Camp 
11, August 23 and September 8 and 18. The first one is in striped juvenile plumage and was probably raised nearby.

160.* Dendroica magnolia. Magnolia Warbler.-Two seen and taken, September 1, at Camp 11, Little Sandhill Creek.

161.* Dendroica striata. Black-POlled Warbler.-Only seen at Camp 11, Little Sandhill Creek, August 28 and September 1. Two specimens, the latter date.

162.* Dendroica virens. Black-throated Green Warbler.But one seen and collected at Camp 11, Little Sandhill Creek, August 17.

163. Dendroica palmarum. Palm Warbler - Two birds seen by Young at Camp 11, Little Sandhill Creek, September 1.

164.* Seiurus aurocapillus. OvEnBIRD.- Heard nearly every day about Camp 1, but none noted again until Young secured two at Camp 11, Little Sandhill Creek, August 27 and September 1.

165.* Seiurus noveboracensis. Northern W Ater-Thrush.-One or two seen nearly every day the last week in August at Camp 11, Little Sandhill Creek, specimens, August 20 and 21. These are referable to S. n. notabilis.

166. Oporoenis philadelphia. Mourning Warbler.-At Camp 1, where warblers were scarce, this was the species most often met with. A mated pair were taken just below Camp 4 near Nevis. In all these birds the abdomen was bare and thickened so they were undoubtedly breeding. Young took another at Camp 11, Little Sandhill Creek, August 17. The male of the Camp 4 pair, is typical philadelphia but the female has the eyelid spots as pronounced as in many female Macgillivray's Warblers. It is evident that females of the two species may be difficult of separation. This specimen unaccompanied by its mate would almost unhesitatingly be referred to $O$. tolmiei. The Camp 11 specimen is also interesting. By skull structure it is a juvenile but is very different in coloration from any other specimen in our collection. It is Empire Yellow below warming to Primuline Yellow, ${ }^{1}$ instead of Lemon Chrome changing to Sulphur Yellow on neck and throat as is shown by comparable August and September material from Point Pelee, Ontario. However, fall specimens of this species are scarce in collections and I have no fall juveniles of tolmiei for comparison and include it under philadelphia on the strength of accompanying specimens.

167.* Geothlypis trichas. Maryland Yellow-throat.- Sparingly distributed but seen practically throughout the trip and becoming a little more common as we descended. The last week in August they were fairly common at Camp 11 on the Little Sandhill Creek but thinned out after the first of September. Specimens from Camps $4 \frac{1}{2}, 8$ and 11. In harmony with the findings of the A. O. U.C ommittee as indicated in the ' Check-list,' I am inclined to refer our Canadian prairie Yellow-throats to occidentalis rather than to trichas, of brachidactyla, as some of them have been designated by Oberholser. In fact I find them easily distinguishable from 
birds of eastern Canada and almost if not quite inseparable from B. C. specimens determined as arizela by the same authority. For the present, I prefer to regard these birds as $G . t$. occidentalis.

168.* Wilsonia pusilla. Wilson WArbler. - Not seen until August 21 at Camp 11 on the Little Sandhill Creek after which one or two were seen every other day until September 18. Specimens, August 21 to September 18. These were well marked $W . p$. pileolata. Some are rather small for this form but the colors are distinctive.

169. Wilsonia canadensis. CANAdian WARBler.- Reported by Young at Camp 1, but not noted again.

170.* Setophaga ruticilla. Redstart-- Only seen at Camp 11 on the Little Sandhill Creek between August 26 and September 6. Specimen, Camp 11, August 27.

171.* Anthus rubescens. American Pipit.-Pipits appeared in large flocks on the prairie level near Camp 11, Little Sandhill Creek, September 12, but were not noted after the 17th.

172.* Anthus spraguei. SPRAGUE's Pipit.-Only seen once by Young at Camp 11, Little Sandhill Creek, September 13. He says it hid in the holes made by the feet of horses and cattle, allowed close approach, flushing like a grouse. Specimen Camp 11, September 13. From Farley's notes it evidently occurs at Red Deer but is more common in the vicinity of Camrose.

173.* Dumetella carolinensis. CATBIRD.-Fairly common along the whole river. At Camp 11, Little Sandhill Creek, they fed upon Buffalo berries. None were noted after September 7. Specimens, Camp 2 and 11.

174.* Toxostoma rufum. Brown Thrasher.- Only seen occasionally at Camp 11 on the Little Sandhill Creek. None observed after September 1. Specimen, Camp 11, August 6.

175.* Salpinctes obsoletus. Rock Wren.- Not seen until we reached Camp 11, on the Little Sandhill Creek. There they appeared fairly common, the greatest numbers being observed about the first of August, when fifteen were noted. The last was observed September 5 . Specimens July 20 to 31 .

176. ${ }^{*}$ Troglodytes aëdon. House WREN. - Fairly common everywhere but very shy. I do not think the song of the western birds is such a spontaneous bubbling over as is the case of our eastern ones. It is thinner and more restrained. At Camp 2 we found it occupying old Cliff Swallow nests. Common at Camp 11, Little Sandhill Creek until after the first of September when it gradually became less numerous. Specimens 6, from Camps 1, 8, 11 all T. a. parkmani.

177. Telmatodytes palustris. Long-BILled Marsh Wren.-Farley lists it in May and June at Red Deer and Horsbrough reports numerous nests around Buffalo Lake.

178. Sitta canadensis. Red-Breasted Nuthatch.- About Camp 1, we several times heard Nuthatch voices but were unable to trace them to their origin and we cannot be certain of the species. Young took one at Camp 11 on the Little Sandhill Creek, August 21, feeding on woolly 
aphides on the cottonwoods. Neither Farley or Horsbrough report this species in the breeding season though Fleming has Red Deer specimens taken June 10.

179.* Penthestes atricapillus. BlaCK-CAPPed Chickadee.-Chickadees were fairly common all along the river. In most cases they seemed to be cruising about in family groups not yet separated. Five specimens all juvenile, from Camps 1, 3, 8 and all have the extreme white feather marginations and long tails of $P . a$. septentrionalis.

180. Penthestes hudsonicus. Hudsonian Chickadee.- Under $P$. hudsonicus, Horsbrough lists this species as a common resident and reports a nest. I have no further records for the vicinity.

181.* Regulus calendula. Ruby-CRowned Krnglet.-Occasional birds seen at Camp 11 on the Little Sandhill Creek from the end of August to the end of Young's stay becoming more common latterly. Specimen, Camp 11, August 29.

182.* Hylocichla fuscescens. Wilson's Thrush.- Fairly common as far down the river as Camp 9 below Rosedale Mines. Most of the records are based upon their notes as all thrushes were exceedingly shy.

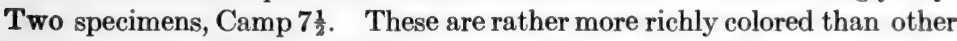
birds from about Edmonton, less olive and more nearly like eastern specimens. I am doubtful as to the exact subspecific status of these specimens but refer them to $H$. s. salicicola with reservations.

183.* Hylocichla ustulata. Olive-Backed Thrush.-Thrushes though common enough were very difficult to identify as they were very shy and only fleeting glimpses were caught of them as they slunk away through the brush, One Olive-back was taken at Camp 11, Little Sandhill Creek, September 17. Horsbrough reports nests at Sylvan Lake.

184.* Hylocichla guttata. Hermit Throsh.-For the above reasons I only care to specifically pronounce upon the one bird taken at Camp 11, Little Sandhill Creek, September 22.

185.* Planesticus migratorius. American Robin.- Common all along the river. At Camp 11, Little Sandhill Creek, Young says they fed extensively upon Buffalo berries. Specimens, Camp 11, September 7 to 21 . Horsbrough refers his birds to the western form $P$. m. propinquus, a rather questionable decision.

186.* Sialia currucoides. Mountain Bluebird-- Some Bluebirds glimpsed in the outskirts of the city of Red Deer and whilst driving from the river to Nevis, Camp 4, we attributed to this species. Several times below Camp 4 we noted individuals amongst the eroded cliffs and hills but could not get close enough to identify them satisfactorily. It was not until we reached Camp 11, on the Little Sandhill Creek that the species was certainly recognized. Here we found them common, feeding upon Saskatoon berries, and later according to Young on Buffalo berries. They remained common up to the time he left and he noted a flock of one hundred birds, September 8. Seven specimens Little Sandhill Creek, July 20 to September 8. Both Farley and Horsbrough report it common at Red Deer. 


\section{ADDENDA.}

We have received in addition to the specimens already cited the following, collected by Dr. R. M. Anderson, Western Grebe, Echmophorus occidentalis, Dried Meat Lake, near Camrose, September 20, 1918. Horned Grebe, Colymbus auritus; Greater and Lesser Yellow-legs, Totanus melanoleucus and T. flavipes; Ruffed Grouse, Bonasa umbellus from Miquelon Lake, near Camrose, September 29, 1918.

The following species and notes should be added to the previous list:

187.* Larus philadelphia. Bonaparte's GulL.-Farley reports this species May 1, 1900 at Red Deer and May 13 and 16, 1917 at Camrose. Anderson took a specimen, September 29, 1918 at Miquelon Lake.

(12). Phalacrocorax auritus. Double-crested Cormorant.-Farley reports that for many years this species bred on Miquelon Lake some 24 miles southeast of Edmonton where Anderson found evidence in September, 1918 of the current year's nesting in the form of nests said to be Cormorant's.

(13). Pelecanus erythrorhynchos. White Pelican.- Said by Farley to have nested in numbers at Miquelon Lake until of late years and it is not known as yet where they have removed to. At the height of their nesting from 300 to 500 nests were to be seen on an island of not three acres extent.

(25). Clangula clangula. GoldenEYe. - Farley reports that for the past eight years Goldeneyes have nested in a blind brick chimney on the R. B. Price house in Camrose, about five feet down. The young clamber up the flue to the top, tumble off and roll down the roof to the ground where they are gathered up and conveyed to the water by human friends, where the mother invariably awaits to receive them. Every spring ducks visit many chimneys in town as if prospecting for nesting sites. My informant queries, "Would these be the young that have remembered a similar nesting home?" The facts suggest the affirmative.

(29). Chen hyperboreus. Snow Goose.-Fleming informs me that he has examined the head of one of Horsbrough specimens, probably one of those he cites, and declares it to be the Lesser, $C$. h. hyperboreus.

(35). Ardea herodias. Great Blue Heron.-Anderson on an island in Miquelon Lake, September, 1918 found nests of this species together with those of Cormorants on the ground. The specific identity was supplied by Mr. Farley and other good report.

(36). Grus mexicana. Sandhill Crane.-Farley reports finding a crane nest on Spotted Lake near Buffalo Lake in May 1895. Dr. George of Red Deer also informs me that he took crane eggs on a small pond near Innisfail May 24, 1896. Undoubtedly these were G. mexicana.

188. Grus americana. Whooping Crane.-Dr. George of Red Deer informs me that he has not seen Whooping Cranes near Red Deer for some years, inferring their former presence but stating that he never found them breeding. 
189. Coturnicops noveboracensis. Yellow RAIL-- Mr. Farley says,- "I know of a swamp at Red Deer where a pair nested several years. Their note is just like two stones knocked together quickly. There is also a pair in a swamp just off our farm (Camrose) where I can depend upon hearing them every June."

(42). Macrorhamphus griseus. Dowitcher. - In the previously published part of the list, antea, p. 12, under this species heading I made an unfortunate slip of the pen when I said that Horsbrough ascribes this "probably incorrectly to the western race, $M . g$. scolopaceus." It should have read " the eastern race, $M . g$. griseus, which makes my implied criticism more intelligible. Fleming sends me measurements of a Buffalo Lake bird, August 1915, which he refers to griseus though he says the color characters tend towards scolopaceus. I infer from his remarks that this is an adult and not a juvenile bird.

190.* Pisobia bairdi. BAIRD's SANDPIPER.-We have a specimen taken by Anderson, Many Island Lake, September 18, 1918.

191. Pelidna alpina. RED-BACKed SANDPIPER.- Mr. Farley reports "Black-heart Plover" May 11, 1899 at Red Deer. This is an old South Ontario name for this species.

(47). Bartramia longicauda. Upland Plover.- Farley notes that this species is rapidly disappearing from this section, a condition he called attention to in the Ottawa Naturalist XXVII, 1913, p. 63. He now lays the blame upon the boys who find it a too easy object of sport through the summer.

(50). Numenius longicauda. Long-Billed Curlew.- Farley substantiates the hypothetical identity of this species reported by Horsbrough and Sternberg, recording it from both Red Deer and Camrose.

(51). Squatarola squatarola. Black-Bellied Plover.-Charadrius dominicus. Golden Plover.- J. H. Fleming writes me that he has the specimens that Horsbrough records as Golden Plover and that they prove to be Black-bellies. Thus the Golden should be replaced by the Black-bellied in the authenticated list.

192. Buteo platypterus. Broad-winged Hawk.- Fleming informs me he has a specimen, Little Hay Lake, (near Camrose) September 2, 1918.

Falco rusticolus. Gyrfalcon- - J. H. Fleming tells me he has the specimen reported under this head by Horsbrough which he regards as rusticolus.

193. Aquila chrysaëtos. Golden Eagle.- Farley reports,- " seen nearly every November at Red Deer.

(78). Bubo virginianus. Great Horned Owl-- Sonema, 5th line second paragraph should be "Lousana."

194. Nyctea nyctea. SNowy OwL.-Farley remarks in letter of November 18, 1918, from Camrose,- " A friend saw a Snowy Owl yesterday," thus giving evidence for the inclusion of this species of undoubted occurrence. 




\section{University of Toronto \\ Library}

恶总

DO NOT

REMOVE

THE

CARD

FROM

THIS

POCKET

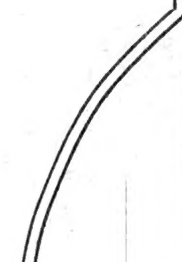

c.

(a) 8

$-10$

ㅇ․

(4)

i)

c) 4

(1) थ

G.

冚总

Acme Library Card Pocket

LOWE-MARTIN CO. LIMITED 
